\title{
Strategic local tax interactions: Do quality of life matters?
}

Francisco J. Delgado ${ }^{a}$

Santiago Lago-Peñas ${ }^{b}$

Matías Mayor ${ }^{\mathrm{c}}$

\footnotetext{
${ }^{a}$ Department of Economics (University of Oviedo) and GEN

http://www.unioviedo.es/fdelgado; fdelgado@uniovi.es

${ }^{\mathrm{b}}$ GEN, IEB and University of Vigo

http://webs.uvigo.es/slagop; infogen@uvigo.es

${ }^{c}$ Department of Applied Economics (University of Oviedo)

http://www.unioviedo.es/matiasmayor; mmayorf@uniovi.es
}

\begin{abstract}
The aim of this paper is to study the role of municipal quality of life as a driver of tax strategic interactions among local governments. The analysis is focused on the two main local taxes in Spain -property tax and motor vehicle tax- and on the municipalities above 50,000 inhabitants. Empirical evidence confirms the existence and relevance of such interactions in the property tax. On the contrary, in the case of motor vehicle tax such interaction patterns are not detected.
\end{abstract}

Keywords: taxation, property tax, tax mimicking, quality of life, strategic interactions JEL Codes: C31, H71, H77 


\section{Introduction}

The analysis of strategic interactions affecting tax policy has received major attention in the literature on local public economics in recent decades. Since the seminal contribution by Tiebout (1956) a number of research vectors has been followed. One of the most relevant concerns the existence of imitation mechanisms affecting municipal tax policy, including the tax mimicking hypothesis and the yardstick competition scenarios (Salmon, 1987; Besley and Case, 1995). Updated reviews of this empirical research vector are provided by Costa-Font, De-Albuquerque and Doucouliagos (2014) ${ }^{1}$ and Delgado, Lago-Peñas and Mayor (2014).

Most certainly, benchmarking requires references. The idea that politicians, voters and other stakeholders look at neighbour municipalities as a shortcut seems reasonable. But how neighbourhood should be understood? This issue is crucial for developing theoretical mechanisms to explain interactions but also for empirical research.

The neighbourhood weight matrix is usually based on geographic proximity: territories sharing borders, distance or k-nearest jurisdictions. But it can also rely upon different socioeconomic characteristics. Some previous studies have focused on per capita income to define the neighbourhood (e.g. Schaltegger and Küttel, 2002), but the GDP is only one of the dimensions of wellbeing and hence it may be a limited measure to describe this phenomenon. To the best of our knowledge, this paper is the first attempt to incorporate differences in quality of life as a driver of strategic tax interactions and this is the major contribution of our research. The motivation is straightforward. Jurisdictions may choose municipalities to be mimicked according not just to proximity in distance terms, but also to their rankings in indicators on social welfare and quality of life, as we explicitly define in the next section. Thus we are assuming in this research that the quality of life indicator may better capture the complex process under location decisions ${ }^{2}$ by individuals and businesses, and in

\footnotetext{
${ }^{1}$ Through a meta-regression analysis and regarding inter-jurisdictional fiscal interactions at the local level of government, they conclude that horizontal tax competition exists although it is weaker that in the county, state or nation level. Another interesting conclusion of this paper is that authors find little evidence of time variation in the magnitude of the interactions.

${ }^{2}$ See Lockwood and Rohlin (2014) for a recent study on interrelations between location-based tax incentives and quality of life and business environment.
} 
consequence also the tax decisions made by the governments. This standpoint presumes the existence of more sophisticated agents, who are aware of differences in quality of life across municipalities and take them into account when they look for benchmarks to evaluate local tax policies.

In contrast with previous studies that generally investigate all municipalities above a relatively small threshold in a certain territory, this research focuses on the largest municipalities. Specifically, the database includes Spanish municipalities over 50,000 inhabitants, considering that the tax imitation processes can be more feasible among neighbour jurisdictions of similar size. Nowadays this case has not been analysed in Spain, ${ }^{3}$ and only Dubois and Paty (2010) have paid attention to the biggest municipalities in France, where the definition of the neighbourhood cannot be based on the contiguity and hence socio-economic variables can be employed to that aim. Concretely, they consider neighbouring cities that are similar in terms of demographic characteristics, specifically the population size.

Finally, this paper is focused on the two main local taxes in Spain, the property tax and the motor vehicle tax, estimating Spatial Lag, Spatial Error and Spatial Durbin models for a cross-section data corresponding to 2009.

The rest of the article is organized as follows. Section 2 describes the empirical strategy. Data and main results are contained in Section 3. Finally, Section 4 concludes.

\footnotetext{
${ }^{3}$ Previous empirical studies on local tax interactions in Spain includes Solé-Ollé (2003), Bosch and SoléOllé (2007), Delgado and Mayor (2011) and Delgado, Lago-Peñas and Mayor (2014). Solé-Ollé (2003) analyzed several local taxes of 105 municipalities in the province of Barcelona for 1992-1999 and found that tax rates were higher with wider electoral margins when there were leftist incumbents and in nonelection years. Bosch and Solé-Ollé (2007) studied the effective rates of local property taxes in 2,799 municipalities for 1991-2003 and concluded the existence of comparative voting behavior, whereby higher taxes translate into lost votes. These two papers used a spatial lag model with cross-products and estimate vote functions. Delgado and Mayor (2011) studied tax mimicking in the main local taxes in a sample of municipalities in the northern Spanish region of Asturias. Estimating both spatial lag and spatial error models for the tax reaction functions, their empirical evidence partially supports the existence of tax mimicking. Finally, Delgado, Lago-Peñas and Mayor (2014), with a sample of 2,713 Spanish municipalities, find support for the hypothesis of tax mimicking (coefficients above 0.40) and certain relevance of political variables such as the ideology and political fragmentation. Additionally, incumbents with weaker political support exhibit stronger mimicking behavior (yardstick competition) and incumbents mimic neighboring municipalities ruled by the same political party (political trends hypothesis).
} 


\section{Theoretical background and empirical strategy}

Following Brueckner (2003), the theoretical models underlying most of the empirical studies in the field of the strategic interaction among governments can be grouped into two categories: spillover models and resource-flow models, although lead to similar empirical specifications. The former include environmental models (Fredriksson and Millimet, 2002) and yardstick competition models, and the latter tax competition ${ }^{4}$ and welfare competition models. In all these models a reaction function shows how the choices made by one jurisdiction may depend on the choices made by other jurisdictions.

Our empirical strategy to analyse interactions among jurisdictions also relies on a tax reaction function estimated through spatial econometric models. The definition of the weight matrix (W) capturing potential linkages between the neighbouring is a first and key step. We assume that the tax decisions are based not only on the own municipal characteristics, but also on those of the neighbouring jurisdictions, and the quality of life is, or can be, one of them ${ }^{5}$. Hence we consider that the comparison in these terms can affect the spatial processes of fiscal competition. Both expenditure level and the quality of the services in each municipality are analysed with tax borne in mind.

To configure the matrix based on quality of life indicators - explained below- we consider previous works in the literature. Its translation to the present case is direct. Hence Case et al (1993) suggest the construction of weights based on economic distance as follows:

$$
\mathrm{w}_{\mathrm{ij}}=\frac{1}{\left|\mathrm{y}_{\mathrm{i}}-\mathrm{y}_{\mathrm{j}}\right|}
$$

By contrast Boarnet (1998) relies upon matrixes which assign a bigger spatial weight as bigger the similarity among the territories is, according to the expression:

\footnotetext{
${ }^{4}$ Wilson (1986) and Zodrow and Mieszkowski (1986). See Wilson (1999) for a review of theories of tax competition.

${ }^{5}$ By extension, individuals and firms can make their basic decisions on location depending on several determinants as tax and expenditure levels, but also the quality of life can result relevant in these processes.
} 


$$
\mathrm{w}_{\mathrm{ij}}=\frac{1 /\left|\mathrm{y}_{\mathrm{i}}-\mathrm{y}_{\mathrm{j}}\right|}{\sum_{\mathrm{j}}\left|\mathrm{y}_{\mathrm{i}}-\mathrm{y}_{\mathrm{j}}\right|}
$$

In both cases, the weights are the result of comparisons, that is, they use distance measures or similarity indicators. But it is widely known that the procedure of elaboration of the $\mathrm{W}$ matrix is an open and debatable question to date. There are several possible specifications and few agreements regarding the criterions, depending on the specific study, available data, and so on. The use of definitions that include parameters may be troublesome in the estimation and inference procedures, and it leads us to a specification based on a binary matrix when the problem is in the model errors. However, as the perspective is the modeling of spatial data, the weights structure that condition the covariance structure should be based on the spatial interaction theory and, hence, get some distance measure.

Recently, Liu and Martínez-Vázquez (2014) empirically address this issue of how to build up the spatial weight matrix. They choose to follow the recommendation by Case et al. (1993) arguing that "neighbourliness does not necessarily connote geographic proximity”. Municipalities may consider as neighbours other municipalities that are similar to them economically, i.e. "spatial interactions do not have to be restricted" to their geographic neighbourhood, but can occur over longer distances if jurisdictions are similar in an economic sense" (Janeba and Osterloh, 2013). Liu and Martínez-Vázquez (2014) propose a different spatial weight matrix using a combination between physical distance and economic similarity using GDP per capita. Moreover, Hauptmeier, Mittermaier and Rincke (2012) propose a spatial weight matrix taking into account both the physical distance between municipalities and their different size in terms of population and Corrado and Fingleton (2012) claim for a major research and justification in the elaboration of the weight matrix by using economic variables ${ }^{6}$.

\footnotetext{
${ }^{6}$ Most studies in the spatial econometric field use exogenous spatial weight matrix based on geographical boundaries and distance. However, there are a significant number of applications where the spatial weight matrix is built using economic variables or variables linked with the analyzed problem. These matrices could be considered as endogenous but the estimation procedure does not incorporate explicitly this issue. Thus, the debate about the advantages and disadvantages of the use of exogenous or endogenous spatial weight matrices is not new, but recently recovered. Kelejian and Piras (2014) analyze different studies where the weighting criteria may not be considered as exogenous. Specifically, they analyze the use of endogenous matrices in a panel data framework and propose an IV estimation procedure to include explicitly the endogeneity issue associated to the weighting. However, this procedure is improved by Qiu and Lee (2015) modelling directly the source of endogeneity and proposing three methods: 2SIV, QMLE
} 
In our opinion, if economic and social issues matter for defining benchmarking peers, the weight matrix should be based on complex quality of life indexes to be able to capture the several dimensions potentially relevant. Fortunately, Gonzalez, Carcaba and Ventura (2011) provide recent and complete estimates for the Spanish municipalities. Their index is based on a Value Efficiency Analysis (VEA) ${ }^{7}$ and cover aspects related to consumption, social services, housing, transport, environment, labour market, health, culture and leisure, education and security, representing eight of the nine dimensions outlined by Stiglitz, Sen and Fitoussi (2009). Hence our main weight matrix will combine distance with the index by Gonzalez, Carcaba, and Ventura (2011).

A second methodological issue concerns the model specification. In this case, we have chosen to follow three complementary approaches. We estimate spatial lag, spatial error and spatial Durbin models to study the tax mimicry hypothesis, using Likelihood Ratio tests to select the most appropriate model in each case. Furthermore, the effects of ideology and incumbent's electoral support are analysed through a tworegime model.

The spatial lag model (SLM) follows the expression:

$$
T=\rho W T+\beta X+\varepsilon
$$

where $T$ is the tax vector, $X$ is a vector of control variables including demographic, socioeconomic and political variables, and $W$ is the weight matrix. In this case, the focus is on the spatial parameter $\rho$.

Another way of modelling spatial autocorrelation is the inclusion of a spatial process in the error term. This model is named the spatial error model (SEM). The most common solution is the consideration of a spatial autoregressive process:

and GMM. In an opposite work line, recently Halleck Vega and Elhorst (2013) recover the construction of weights based on the distance subject to a parameters to be estimated jointly with the rest of the model parameters.

In this present study, we are not using an economic variable closely linked to the dependent variable but we use a quality of life index to compute the distance among municipalities. We think that the significance of the endogeneity issue associated to the spatial weight matrix is not meaningful in this case. For example, if GDPpc or another economic variable is used, it is likely that these values are finally correlated with the final outcome. The existence of this correlation between the synthetic quality of life index and the dependent variable seems less probable.

${ }^{7}$ VEA is a weights restriction method that allows incorporate qualitative information into the Data Envelopment Analysis (DEA) specification, a non-parametric frontier analysis method extended in the efficiency literature. For detailed information regarding VEA see Halme et al. (1999). 


$$
T=\beta X+(I-\lambda W)^{-1} \xi+\varepsilon ; \varepsilon \sim N\left(0, \sigma^{2} I\right)
$$

where $\lambda$ is the spatial autoregressive coefficient associated to the error spatial lag and $\varepsilon$ is an uncorrelated and homoscedastic error term. There are other alternative way of incorporating spatial autocorrelation in the residuals, but there are not commonly used in empirical exercises. For example, Cliff and Ord (1981) proposed the specification of a spatial moving average error process, and Kelejian and Robinson (1993, 1995) developed a similar solution which is named the spatial error components model.

The bulk of empirical papers rely upon these two models. However, any spatial pattern in the data should be explained by three factors: endogenous interaction effects, exogenous interaction effects and correlated error interactions (Manski, 1993). In the case of yardstick competition as a source of tax interactions, the empirical solution should consider those three types of interactions (Elhorst and Fréret, 2009). This discussion is closely related to the strategy followed during the specification stage. Most of the empirical papers choose the simple spatial lag and/or spatial error model because they use a bottom-up strategy applying the Lagrange Multiplier tests (Florax, Folmer and Rey, 2003). By the contrary, Mur and Angulo (2009), Elhorst (2010) and LeSage and Pace (2009) show some advantages of a general to specific strategy using a more complete model as departure point. They propose the use of the Spatial Durbin Model (SDM) including both endogenous and exogenous interaction effects. The spatial interaction in the error term is excluded avoiding identification problems.

$$
T=\rho W T+\beta X+\beta^{\prime} W X+\varepsilon
$$

This is the preferred model taking into account its behavior against different spatial process even if a battery of test should be conducted to choose among the alternatives, using Likelihood Ratio tests. Furthermore, the specification of a SDM allows the consideration of different sources of spatial interaction through the spatial lag of the explanatory variables set. Finally, from an econometric point of view, the existence of unobserved or omitted spatially correlated variables does not generate a bias in the estimated coefficients.

Within the hypothesis of yardstick competition, the models described above are complemented allowing for two spatial regimes identified by a dummy variable $(D)$. We 
focus on the ideology and majorities. Hence, in the ideology setting, $D$ is coded 1 in case of leftist governments and 0 otherwise. $B$ is a diagonal matrix $(n \times n)$ with diagonal elements equal to 1 when $D=1$ and $(I-B)$ is its complementary matrix with diagonal elements equal to 1 when $D=0 . B W T$ is the average tax rate of the neighboring municipalities with leftist governments while $(I-B) W T$ is the average tax rate of the neighboring municipalities with rightist incumbents.

$$
T=\rho_{D=1} B W T+\rho^{\prime}{ }_{D=0}(I-B) W T+\mu_{D=1}+\mu_{D=0}^{\prime}+\beta X+\varepsilon
$$

where parameters $\rho_{D=1}$ and $\rho_{D=0}^{\prime}$ measure the intensity of the tax interaction of municipalities belonging to the first and the second regimes respectively. If fiscal policy interaction is driven by yardstick competition, we expect the interaction coefficient $\rho_{D=1}$ to be significantly different than the interaction coefficient $\rho_{D=0}^{\prime}$. Different political regimes may also set different taxes regardless of the explanatory variables and the tax mimicking behavior. Two different intercepts $\left(\mu_{D=1}\right.$ and $\left.\mu_{D=0}^{\prime}\right)$ are therefore included in the model to capture this possibility. A similar approach is followed when we study the effect of majorities.

Four different methods can be adequate to estimate models that include spatial interactions: Maximun Likelihood (ML), Instrumental Variables (IV), Generalized Method of Moments (GMM), and the Bayesian Markov chain Monte Carlo method (MCMC). In the 80s and 90s, a problem with the latter method was its computational cost, a task that is now resolved. In this case, the models described above are estimated by means of ML. Additionally, the use of ML for estimating two spatial-regimes model guarantees that the estimated interaction effect is restricted to the previously defined values and this is one of the advantages of this method for testing yardstick competition (Elhorst and Fréret, 2009). The GMM-IV alternative would require the choice of a set of instruments at a municipal level which in some case would be difficult due to data scarce.

Once the different proposed models have been estimated, the coefficients on the explanatory variables should not be interpreted directly, i.e. assuming a linear relationship. Only when the estimated model has the form of the SEM, the coefficient estimates can be directly interpreted. For instance, in the case of the SLM (and also in the SDM) it is necessary to take into account the fact that any change in the dependent 
variable in one municipality may affect the values of this variable in all municipalities, following the spatial interactions structure introduced in the previously defined spatial weight matrix. Thus, a change in one explanatory variable in the municipality $i$ will not only generate a direct effect on its own value, but also an indirect effect on the tax values of other municipalities. As a consequence, the impact of a change in one explanatory variable has on the dependent variable of a jurisdiction is not usually equal to its estimated coefficient.

Then the effect of the explanatory variables on the dependent variable has not a straightforward interpretation, and direct and indirect effects must be computed. Following LeSage and Pace (2009) the partial derivatives take the form of an N-by-N matrix for each k regressor and comments on their fundamental properties. For instance, the partial derivates matrix corresponding to whichever independent variable would have the following form in the case of a SDM:

$$
\frac{\partial \mathrm{T}}{\partial \mathrm{X}}=(\mathrm{I}-\rho \mathrm{W})^{-1}(\beta \mathrm{I}+\theta \mathrm{W})
$$

These authors propose scalar summary averages to increase the ease of reporting the effects associated with the regressors; thus, direct effects measure what effect changing an independent variable has on the dependent variable of a territory. This measure includes feedback effects, i.e., those effects passing through neighboring units and back to the unit that instigated the change. The cross-partial derivatives are named indirect effects, and they measure the effect of changing an independent variable in a jurisdiction on the dependent variable of all the other territories. Indirect effects appear as off-diagonal elements and are summarized as row sum averages. Finally, total effects are computed as the sum of direct and indirect effects.

\section{Data and results}

We consider the Spanish municipalities above 50,000 inhabitants ${ }^{8}$. This threshold is the used in Spanish law to define big jurisdictions. Those jurisdictions have responsibility

\footnotetext{
${ }^{8}$ Municipalities located in Navarre and the Basque Country are excluded due to the very particular federal fiscal agreements in both regions. Additionally, we do not study the Balearic and Canary Islands.
} 
on more expenditure powers than the smaller municipalities. Mixing them in the same sample would involve troublesome heterogeneity. Moreover, political debates in those municipalities tend to receive much more attention from local and regional mass media, involving more transparency and information on tax choices. Interactions, if present, should be stronger in the case of biggest municipalities.

With regard to local taxation, in 2009 the property tax represented the 57.37 per cent of local tax collection, being clearly the main local tax source, while the motor vehicle tax provided the 14.06 per cent ${ }^{9}$. Hence, these two figures, taken together, involve a significant portion of the local tax revenues in Spain. In the case of property tax, local governments can choose a nominal tax rate, normally between 0.4 and 1.1 per cent. This tax rate applies to a cadastral value which is based on the last revision made in the municipality, legally each ten years. Thus, instead of consider the nominal property tax rate ${ }^{10}$, two proxies of the effective taxation are used: the per capita liability and the per receipt liability. In the motor vehicle tax, municipalities choose a coefficient, between 1 and 2 , to be applied to the approved state amounts ${ }^{11}$. We consider the case of the automobiles for which there exists five categories depending on its potency, and we calculate the average coefficient approved by the jurisdiction.

Table 1 summarizes the list of explanatory variables, classified into three groups. Concerning the sample, cross-section data for year 2009 is used ${ }^{12}$. Descriptive statistics of all variables are reported in Table 2.

\footnotetext{
${ }^{9}$ The other three compulsory local taxes in Spain collect only the 8.81, 7.10 and 6.95 per cent respectively.

${ }^{10}$ The nominal property tax rate has been analyzed by Delgado, Lago-Peñas and Mayor (2014) for the Spanish municipalities above 5,000 inhabitants. The interaction parameter was 0.22 in the spatial lag specification and 0.48 in the spatial Durbin model.

${ }^{11}$ Concretely, the reference state liabilities are the following for the five automobile categories considered in the Spanish motor vehicle tax: $12.62,34.08,71.94,89.61$ and 112.00 euros. Then the municipality choose a coefficient between 1 and 2 and hence the final liability will be between $12.62-25.24$ and $112.00-224.00$ euros for the first and last categories respectively.

${ }^{12}$ This is an inter-electoral year. Following Delgado, Lago-Peñas and Mayor (2014) panel data allow for control of unobserved fixed local specifications, while the cross-sectional approach allows for a large data domain and avoids problems posed by structural changes. With regard to the possible shortcoming of cross-sectional data, upward bias of the estimated coefficients of the spatial lags due to an omitted variation problem, which might be captured by fixed effects, LeSage and Pace (2009) show that spatial Durbin models do not suffer from amplified bias. Additionally, Anselin and Arribas-Bel (2013) investigate whether the introduction of spatial fixed effects in a regression of a single cross-section eliminates spatial dependencies and their results indicate that the use of spatial fixed effects will not suffice to correct for the presence of spatial correlation.
} 


\section{[Tables 1 and 2 near here]}

The first step of the empirical work is the computation of the commonly used Moran I statistic in order to test the presence of spatial autocorrelation on the residuals of the proposed model using Ordinary Least Squares (OLS). Both measures regarding property tax show positive and significant spatial autocorrelation, whereas the statistic value for the vehicle motor tax is not statistically significant to reject the null hypothesis of non-spatial autocorrelation (see Table 3). However, it is necessary to bear in mind that Moran test is designed to detect global spatial autocorrelation patterns so we cannot neglected the existence of local spatial autocorrelation processes (i.e. spatial regimes).

[Table 3 near here]

As explained above, we follow the specification strategy proposed by Elhorst (2010) which may be understood like a combination between specific to general and general to specific strategies. Once the model has been estimated by OLS, we use the LM test and its robust version to determine whether a spatial lag or spatial error specification is preferable. Whenever OLS is rejected in favour of any spatial alternative, the spatial Durbin model is taken as a departure point. This model is estimated and compared with the alternative models. In this paper, we applied maximum likelihood method so an LR test can be conducted to determine whether the SDM can be simplified to either the spatial lag $\left(H_{0}: \beta^{\prime}=0\right)$ or the spatial error model ( $H_{0}: \beta^{\prime}+\rho \beta=0$ ). The obtained results are summarized in Table 4 (using quality of life to construct the spatial weights) pointing out that the SDM is the most appropriate to fit the data when the reaction function of the property tax-per capita liability is considered, whereas SDM could be simplified to the SEM in the case of property tax-per receipt liability even though the SDM is preferred against the SLM. When the motor vehicle tax function is fitted the SDM could be reduced to the SLM but SDM cannot be simplified to the SEM model. 
[Table 4 near here]

The main results are presented in Tables 5 ( $\mathrm{k}=4$ nearest neighbours and distance$50 \mathrm{~km}$ ) and 6 (quality of life and combined: distance - $50 \mathrm{~km}$ and quality of life). The results from the $\mathrm{k}=4$ nearest neighbours and distance $-50 \mathrm{~km}$ are considered as benchmarks ${ }^{13}$.

Regarding the property tax, several differences between the two considered indicators are reported. In the case of the per receipt liability, the spatial interaction parameter is significant in several models and weight matrixes, with a spatial parameter around 0.2 in the spatial lag and 0.25 in the spatial Durbin. The significant variables in most models are: young population share, unemployment rate, per capita investment, and per capita deficit. The corresponding coefficient is positive in all cases. Political variables are not significant in general. In contrast, the analysis of the per capita liability in the property tax reveals a significant bigger spatial interaction effect in all proposed models, around 0.2 in the spatial lag and 0.4 in the spatial Durbin. Indeed, now the significant explanatory variables are unemployment rate, per capita deficit, and per capita debt. Regarding the political variables, most of them are neither significant. Only the variable "leftist incumbents" in one model (SDM with quality of life) is significant, with a negative estimated parameter. It should be noted the relevance of the deficit and debt measures to explain the local property tax levels. Due to this tax is the main own revenue source at the local governments, this result reflects certain fiscal coresponsibility.

In the case of motor vehicle tax, we do not find a significant spatial interaction, except for the spatial lag model with 4-nearest neighbours, where the parameter is around 0.1 with significant political variables. This result is expected because the previous autocorrelation tests are not statistically significant to reject the null hypothesis of no autocorrelation in the residuals of the data. However, we will further investigate the two-regime model searching for possible yardstick competition results.

\footnotetext{
${ }^{13}$ Additionally, we have estimated the models with other distances, concretely with 100, 150 and $200 \mathrm{~km}$. The results, not provided in the manuscript but available upon request, are similar to the reported in the paper.
} 
As stated above, it must be noticed that, in general, the political variables do not matter here. This result is different from the achieved by Delgado, Lago-Peñas and Mayor (2014) for Spanish municipalities above 1,000 inhabitants, denoting another interaction pattern depending on the size of the municipalities. With regard to the direct and indirect effects, due to the previous results, we only present the property tax case (Tables 7 and 8). As it was explained above, the direct impacts show the effects of the dependent variable in a municipality $i$ resulting of a change in one explanatory variable in this municipality collecting the influence of the feedback loops where the observation $i$ affects observation $j$ which in turn also affects observation $i$. For example, the estimated coefficient associated to the share of population under 15 years in the SLM for the property tax-per receipt liability is 19.8918 whereas its direct effect (using k-4nn spatial weight matrix) is slightly higher (20.4559) due to the (positive) spatial autocorrelation process. The estimated coefficient for the unemployment rate using the same model (first column of Table 5.a) is 0.2607 which is slightly smaller than its direct impact (0.2663). Similar differences are founded when the results of the SDM are detail analysed. The estimated coefficient for the share of population under 15 years in this case is 19.9945 (third column of Table 5.a) and again its direct impact is slightly higher (20.5707) and statistically significant.

If these results are compared to the estimates obtained using the distance spatial weight matrix (distance 50-km), we observe close differences between the estimated coefficients and their direct impacts. For example, the estimated coefficient for the share of population under 15 years are 18.0133 (SLM) and 19.0394 (SDM) and the direct impacts show slightly changes, 18.3646 and 18.9120 , respectively.

In general terms, we found similar differences between the estimated coefficient of the explanatory variables and their direct impacts. Using as an example the estimates for the per capita deficit variable, the estimated coefficients for the spatial lag model are 0.2850 (K-4nn), 0.2550 (distance 50-km) and 0.3009 (Q-life) whereas the direct impacts are slightly higher due to the spatial interactions among municipalities (including all the municipalities because of the properties of the spatial weight matrix): 0.2870 (K-4nn), $0.2596(50-\mathrm{km})$ and 0.3121 (Q-life), respectively.

As expected, the estimated indirect impacts present more variability. Focusing the attention in the property tax-per capita liability, the estimated indirect impacts 
associated to per capita deficit using a SLM are $0.0710(\mathrm{~K}-4 \mathrm{nn}), 0.0657$ (distance 50$\mathrm{km}$.) and 0.0762 (Q-life) implying that an increase of 1 unit in the per capita deficit in one municipality generates a rising in the property tax-per capita liability of 0.0709 (on average) in the rest of municipalities.

[Table 5 near here]

[Table 6 near here]

[Table 7 near here]

[Table 8 near here]

Within the yardstick competition hypothesis, the results from a two-regime model regarding the effect of the ideology are summarized in Table 9, while the case of majorities is reported in Table 10. Concerning the former, results for the motor vehicle tax are not significant, as occurred in the overall sample in most models. When we analyse the property tax - per receipt liability, the spatial interaction parameter is significant for rightist governments $(0.355)$ but not for leftist governments and the difference is not statistically significant. However, when analysing the property tax per capita liability, the spatial parameters are significant in both sub-samples, but the difference is also not statistically significant despite its size, with 0.368 for left-wing governments and 0.485 for the rest. The size of the subsamples can be the reason for this surprising result, and perhaps this difference would be significant with a bigger sample.

[Table 9 near here]

When the regimes are defined using the existence of majorities, we obtain nonsignificant results for the property tax-per receipt liability and the motor vehicle tax. But again we find an interesting difference between the two sub-samples when the property 
tax-per capita liability is considered: 0.548 for governments with strong majority versus 0.196 for governments with weak majority. These results do not confirm the yardstick competition hypothesis because the estimated spatial autocorrelation coefficient for the strong majority sub-sample is higher -and the difference not significant- pointing out an important degree of tax mimicking among these municipalities, in contrast to the predictions from that hypothesis.

[Table 10 near here]

\section{Conclusions}

The study of strategic fiscal interactions among jurisdictions has converted into a major topic within the local public finance literature in the last decades, searching for mimicking patterns among governments and their explanations, most of them based on the yardstick competition hypothesis instead of tax competition or spillover effects.

An essential choice in the empirical strategy based on spatial econometrics is the weight matrix. While the most often way to define neighbourhood is thinking in terms of geography, politicians, voters and stakeholders can be more sophisticated. This is the standpoint taken in this paper. In spite of more traditional matrixes based just on knearest neighbours or distance, we have primarily investigated if the quality of life is a relevant driver of strategic tax interactions. To this aim a weight matrix combining distance with a quality of life index has been used.

In particular, our database include Spanish municipalities above 50,000 inhabitants and we focus on the two main local taxes, the property tax -with two proxies of the effective taxation: per receipt and per capita liabilities- and the motor vehicle tax. Empirical evidence supports the presence of such interactions in the property tax, especially when we consider the per capita liability, with a parameter interaction around 0.45 in the Spatial Durbin Model. Nevertheless, the estimations from two-regime models depending on the ideology and majorities do not support the yardstick competition hypothesis. In the case of the motor vehicle tax, the tax mimicry is not significant in the whole sample and we do not detect different interaction patterns regarding ideology or incumbents' support. 
To conclude, we can point out several directions for future research. As we consider the quality of life indicator, it would be interesting to explore its components and estimate with several dimensions of the measure. Another extension consists on the consideration of possible "border effects" on the strategic interactions, investigating if and how- jurisdictions choose their tax rates based only on those of their "domestic" neighbours, belonging to the same province or region, or also on the "foreign" fiscal policy beyond their frontiers ${ }^{14}$.

Acknowledgements. Funding from the Instituto de Estudios Fiscales, Grants CSO2013-4703-C2-2-R (Delgado and Lago-Peñas) and CSO2013-43359-R (Delgado), is gratefully acknowledged. The paper has also benefited from insightful comments by Eduardo Gonzalez, Julie Le Gallo, Jorge Martinez-Vazquez and Agnese Sacchi. However, responsibility on the paper is our own.

\footnotetext{
${ }^{14}$ See for example Delgado and Mayor (2014) for a recent review of this approach in the local tax competition setting.
} 


\section{REFERENCES}

Anselin, L. and Arribas-Bel, D. (2013): Spatial fixed effects and spatial dependence in a single cross-section, Papers in Regional Science, 92(1), 3-17.

Besley, T. and Case, A. (1995): Incumbent behaviour: vote seeking, tax setting and yardstick competition, American Economic Review, 85(1), 25-45.

Boarnet, M.G. (1998): Spillovers and the locational effects of public infrastructure, Journal of Regional Science, 38(3), 381-400.

Bosch, N. and Solé-Ollé, A. (2007): Yardstick competition and the political costs of raising taxes: An empirical analysis of Spanish municipalities, International Tax and Public Finance, 14(1), 71-92.

Brueckner, J. (2003) Strategic interaction among governments: an overview of empirical studies, International Regional Science Review, 26(2), 175-188.

Case, A.C., Hines, J.R. and Rosen, H.S. (1993): Budget spillovers and fiscal policy interdependence, Journal of Public Economics, 52, 285-307.

Cliff, A.D. and Ord, J.K. (1981): Spatial Processes: Models \& Applications.

Corrado, L. and Fingleton, B. (2012): Where is the Economics in Spatial Econometrics?, Journal of Regional Science, 52(2), 210-239.

Costa-Font, J., De-Albuquerque, F. and Doucouliagos, H. (2014): Do jurisdictions compete on taxes? A meta-regression analysis, Public Choice, forthcoming.

Delgado, F.J. and Mayor, M. (2011): Tax mimicking among local governments: some evidence from Spanish municipalities, Portuguese Economic Journal, 10(2), $149-164$.

Delgado, F.J. and Mayor, M. (2014): Local tax competition: a brief review and discussion of current research, mimeo.

Delgado, F.J., Lago-Peñas, S. and Mayor, M. (2014): On the determinants of local tax rates: New evidence from Spain, Contemporary Economic Policy, forthcoming, DOI: $10.1111 /$ coep. 12075 .

Dubois, E. and Paty, S. (2010): Yardstick competition: which neighbours matter?, Annals of Regional Science, 44, 433-452. 
Elhorst, J.P. (2010): Applied spatial econometrics: raising the bar, Spatial Economic Analysis, 5, 9-28.

Elhorst, J.P. and Fréret, S. (2009) Evidence of political yardstick competition in France using a two-regime Spatial Durbin Model with fixed effects, Journal of Regional Science, 49(5), 931-951.

Florax, R.J.G.M., Folmer, H. and Rey, S.J. (2003): Specification searches in spatial econometrics: the relevance of Hendry's methodology, Regional Science and Urban Economics, 33, 557-579.

Fredriksson, P.G. and Millimet, D.L. (2002): Strategic interaction and the determinants of environmental policy across US states, Journal of Urban Economics, 51, 101122.

Gonzalez, E., Carcaba, A. and Ventura, J. (2011): Quality of life ranking of Spanish municipalities, Revista de Economía Aplicada, 56, 123-148.

Halleck Vega, S. and Elhorst, J.P. (2013): On spatial econometric models, spillover effects, and $W$, paper presented at the 53rd ERSA Congress, Palermo, Italy.

Halme, M., Joro, T., Korhonen, P., Salo, S. and Wallenius, J. (1999): A Value Efficiency approach to incorporating preference information in Data Envelopment Analysis, Management Science, 45(1), 103-115.

Hauptmeier, S., Mittermaier, F. and Rincke, J. (2012): Fiscal competition over taxes and public inputs, Regional Science and Urban Economics, 42(3), 407-419.

Janeba, E. and Osterloh, S. (2013): Tax and the city - A theory of local tax competition, Journal of Public Economics, 106(C), 89-100.

Kelejian, H.H. and Piras, G. (2014): Estimation of spatial models with endogenous weighting matrices, and an application to a demand model for cigarettes, Regional Science and Urban Economics, 46, 140-149.

Kelejian, H. and Robinson, D. (1993) A suggested method of estimation for spatial interdependent models with autocorrelated errors, and an application to a county expenditure model, Papers in Regional Science, 72, 297-312. 
Kelejian, H. and Robinson, D. (1995) Spatial correlation: a suggested alternative to the autoregressive model, in Anselin, L. and Florax, R.J.G.M.: New Directions in Spatial Econometrics, Springer Verlag, New York, 75-95.

LeSage, J. and Pace, R.K. (2009): Introduction to Spatial Econometrics, Chapman and Hall.

Liu, Y. and Martinez-Vazquez, J. (2014): Interjurisdictional tax competition in China, Journal of Regional Science, 54, 606-628.

Lockwood, C. and Rohlin, S. (2014): Do location-based tax incentives improve quality of life and quality of business environment?, Journal of Regional Science, 54(1), $1-32$.

Manski, C.F. (1993) Identification of endogenous social effects: the reflection problem, Review of Economic Studies, 60, 531-542.

Mur, J. and Angulo, A. (2009): Model selection strategies in a spatial setting: Some additional results, Regional Science Urban Economics, 39, 200-213.

Qu, X. and Lee, L-F (2015) Estimating a spatial autoregressive model with an endogenous spatial weight matrix, Journal of Econometrics, 184(2), 209-232.

Salmon, P. (1987): Decentralization as an incentive scheme, Oxford Review of Economic Policy, 3, 24-43.

Santolini, R. (2008): A spatial cross-sectional analysis of political trends in Italian municipalities, Papers in Regional Science, 87, 431-451.

Schaltegger, C.A. and D. Küttel (2002): Exit, voice, and mimicking behavior: evidence from Swiss cantons, Public Choice, 113 (1-2), 1-23.

Solé-Ollé, A. (2003) Electoral accountability and tax mimicking: the effects of electoral margins, coalition government, and ideology, European Journal of Political Economy, 19(4), 685-713.

Stiglitz, J., Sen, A. and Fitoussi, J.P. (2009): Report of the commission on the measurement of economic performance and social progress (CMEPSP), available at http://www.stiglitz-sen-fitoussi.fr/documents/rapport_anglais.pdf.

Tiebout, C. (1956): A pure theory of local expenditures, The Journal of Political Economy, 64(5), 416-424. 
Wilson, J.D. (1986): A theory of interregional tax competition, Journal of Urban Ecomomics, 19, 296-315.

Wilson, J.D. (1999): Theories of tax competition, National Tax Journal, 52(2), 269-304.

Zodrow, G. and Mieszkowski, P. (1986): Pigou, Tiebout, property taxation and the underprovision of local public goods, Journal of Urban Ecomomics, 19, 356370. 


\section{TABLES}

Table 1

Explanatory variables

\begin{tabular}{|c|c|c|}
\hline $\begin{array}{l}\text { Structural and socio- } \\
\text { demographic features }\end{array}$ & Fiscal indicators & Political factors \\
\hline $\begin{array}{ll}\text { - } & \text { population (in thousands) } \\
\text { - } & \text { area }\left(\mathrm{km}^{2}\right) \\
\text { - } & \text { percentage of population } \\
\text { under } 15 \text { years } \\
\text { - } \\
\text { percentage of population } \\
\text { over } 65 \text { years } \\
\text { - } \\
\text { unemployment rate }\end{array}$ & $\begin{array}{l}\text { - } \text { per capita grants received } \\
\text { - } \text { per capita investment } \\
\text { - } \text { per capita deficit } \\
\text { - } \text { per capita debt }\end{array}$ & $\begin{array}{l}\text { - } \text { ideology }^{1} \\
\text { - } \text { electoral distance }^{2} \\
\text { - } \text { political fragmentation }^{3}\end{array}$ \\
\hline
\end{tabular}

${ }^{1}$ This dummy is coded 1 in the case of leftist governments and 0 otherwise.

${ }^{2}$ To proxy for political support enjoyed by incumbents and confidence in re-election, this variable is defined, following Santolini (2008), as the difference between 100 and the share of the vote of the mayor's political party.

${ }^{3}$ Measured by the Herfindahl index, it is computed as the sum of the squares of the shares of each party's councillors. Hence, the index is 1 if all the councillors belong to one party.

Table 2

Descriptive statistics

\begin{tabular}{lrrrr}
\hline Variable & Mean & S. D. & Minimum & Maximum \\
\hline Dependent variable & & & & \\
Property tax - per capita liability & 227.27 & 90.07 & 102.23 & 588.59 \\
Property tax - per receipt liability & 314.07 & 109.66 & 148.28 & 766.17 \\
Motor vehicle tax rate & 1.78 & 0.21 & 1.06 & 2.00 \\
\hline Explanatory variables & & & & \\
Population (/10,000) & 17.24 & 33.26 & 5.07 & 325.59 \\
Area & 202.39 & 327.94 & 6.85 & 1752.61 \\
Share of population under 15 years & 15.35 & 2.35 & 10.48 & 21.37 \\
Share of population over 65 years & 14.59 & 3.86 & 4.22 & 23.06 \\
Unemployment rate & 3.28 & 1.93 & 0.75 & 12.14 \\
Per capita grants received & 485.99 & 92.21 & 299.28 & 870.08 \\
Per capita investment & 295.32 & 102.68 & 74.58 & 656.54 \\
Per capita deficit & -27.33 & 128.57 & -463.12 & 415.23 \\
Per capita debt & 581.09 & 305.60 & 68.31 & 2081.38 \\
Leftist incumbent & 0.54 & 0.50 & 0.00 & 1.00 \\
Electoral distance & 48.89 & 10.59 & 20.00 & 84.00 \\
Political fragmentation & 0.42 & 0.08 & 0.24 & 0.67 \\
\hline So
\end{tabular}

Sources: Spanish Ministry of Economics and Public Finance, Spanish Home Office, Spanish Ministry of Public Administrations, Spanish Statistics Institute (INE). N=125. 
Table 3

Global autocorrelation test

\begin{tabular}{llll}
\hline & $\begin{array}{l}\text { Property tax }- \\
\text { per receipt liability }\end{array}$ & $\begin{array}{l}\text { Property tax }- \\
\text { per capita liability }\end{array}$ & Motor vehicle tax \\
\hline Moran & 0.106 & 0.2609 & 0.040 \\
Moran I-statistic & 2.032 & 5.428 & 0.977 \\
p-value & 0.020 & 0.000 & 0.328 \\
\hline
\end{tabular}

Table 4

Results for the specification tests

\begin{tabular}{lccc}
\hline & $\begin{array}{l}\text { Property tax } \\
\text { per receipt } \\
\text { liability }\end{array}$ & $\begin{array}{l}\text { Property tax }- \\
\text { per capita } \\
\text { liability }\end{array}$ & $\begin{array}{l}\text { Motor vehicle } \\
\text { tax }\end{array}$ \\
& $25.70^{* *}$ & $39.16^{* * *}$ & 20.26 \\
LR $\left(\mathrm{H}_{0}: \beta^{\prime}=0 ; \mathrm{SLM}\right)$ & 20.90 & $26.10^{* *}$ & $19.48^{* *}$ \\
$\mathrm{LR}\left(\mathrm{H}_{0}: \beta^{\prime}+\rho \beta=0(\mathrm{SEM})\right)$ & & &
\end{tabular}

***, $* *$ significant at $1 \%$ and $5 \%$ respectively 
Table 5. Tax mimicry: $\mathrm{k}=4$ nearest neighbours and distance-50 km

5a. Property tax: per receipt liability

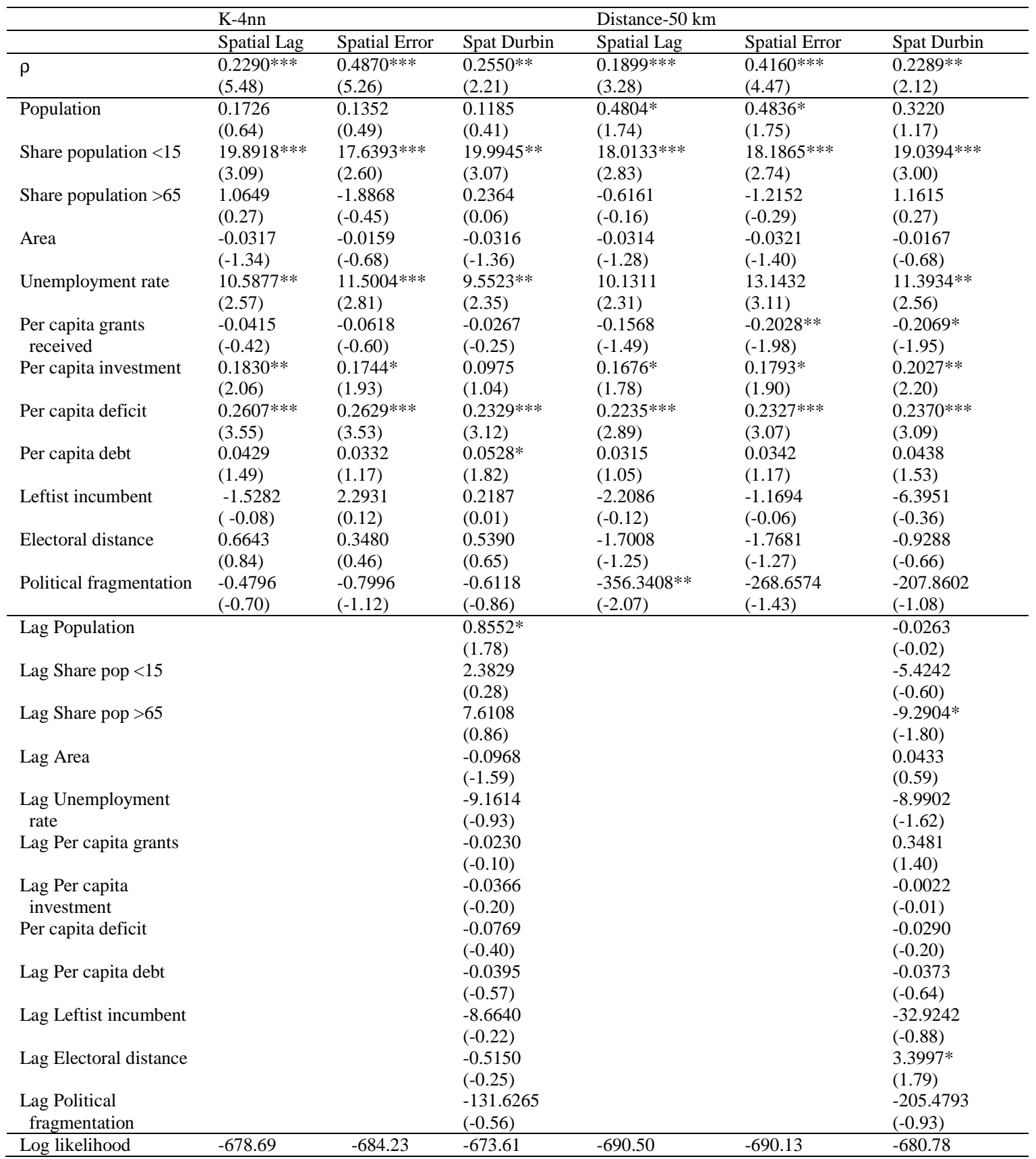

Source: own elaboration

$* * *, * *$ and $*$, significant at $1 \%, 5 \%$ and $10 \%$ respectively 
5b. Property tax: per capita liability

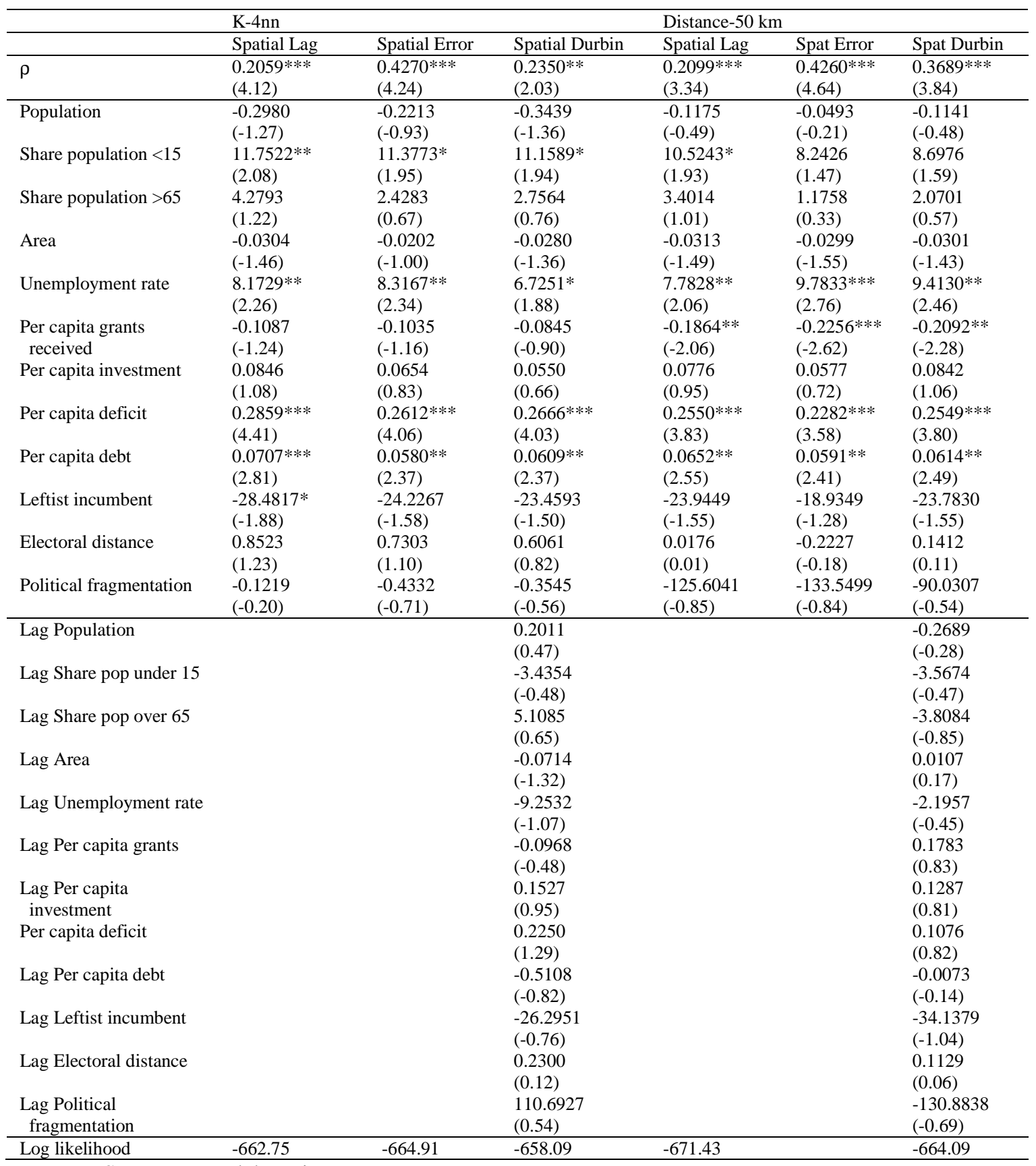

Source: own elaboration

$* * *, * *$ and $*$, significant at $1 \%, 5 \%$ and $10 \%$ respectively 
5c. Motor vehicle tax

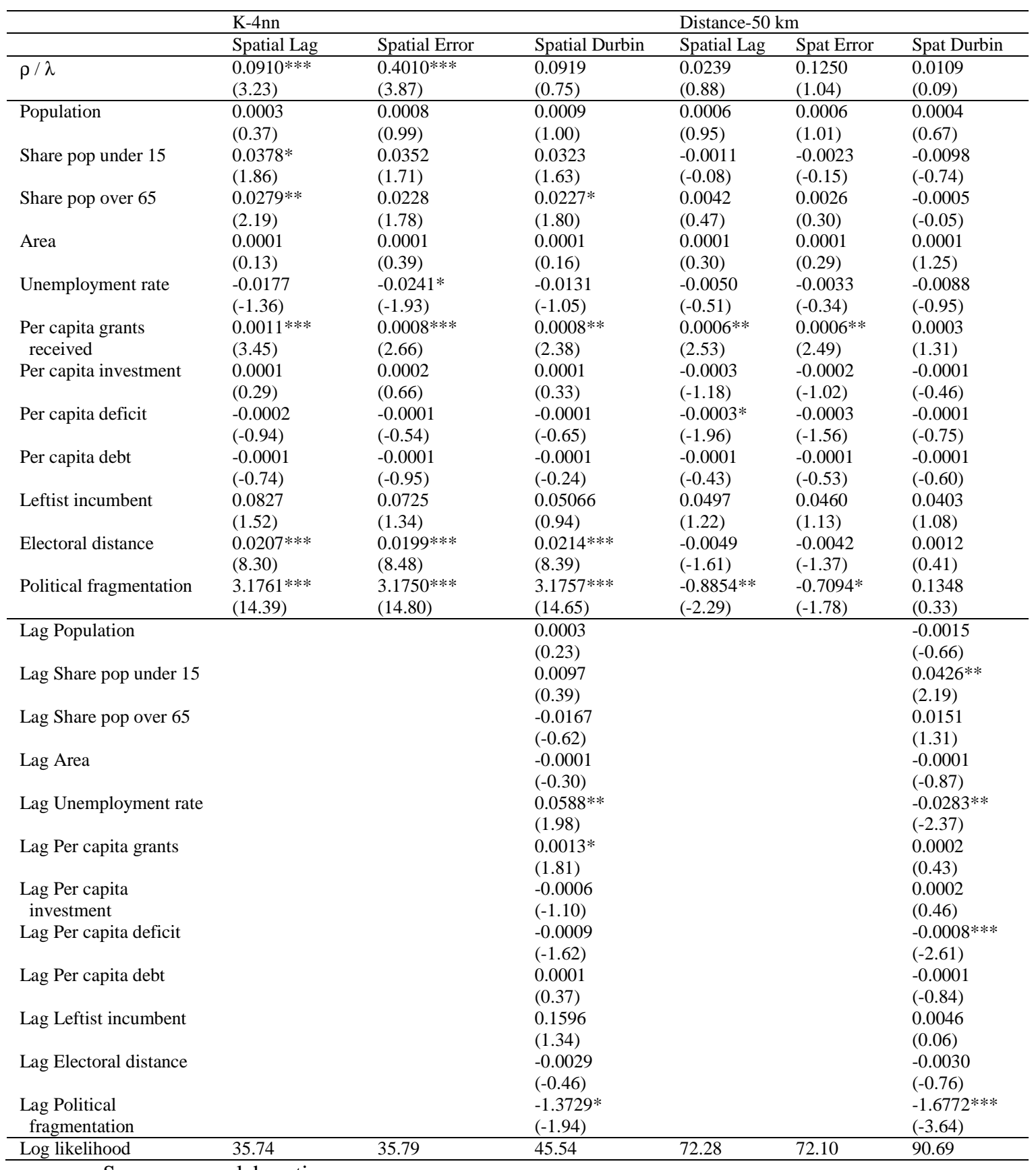

Source: own elaboration

$* * *, * *$ and $*$, significant at $1 \%, 5 \%$ and $10 \%$ respectively 
Table 6. Tax mimicry: quality of life and combined (distance-50 \& quality of life)

6a. Property tax: per receipt liability

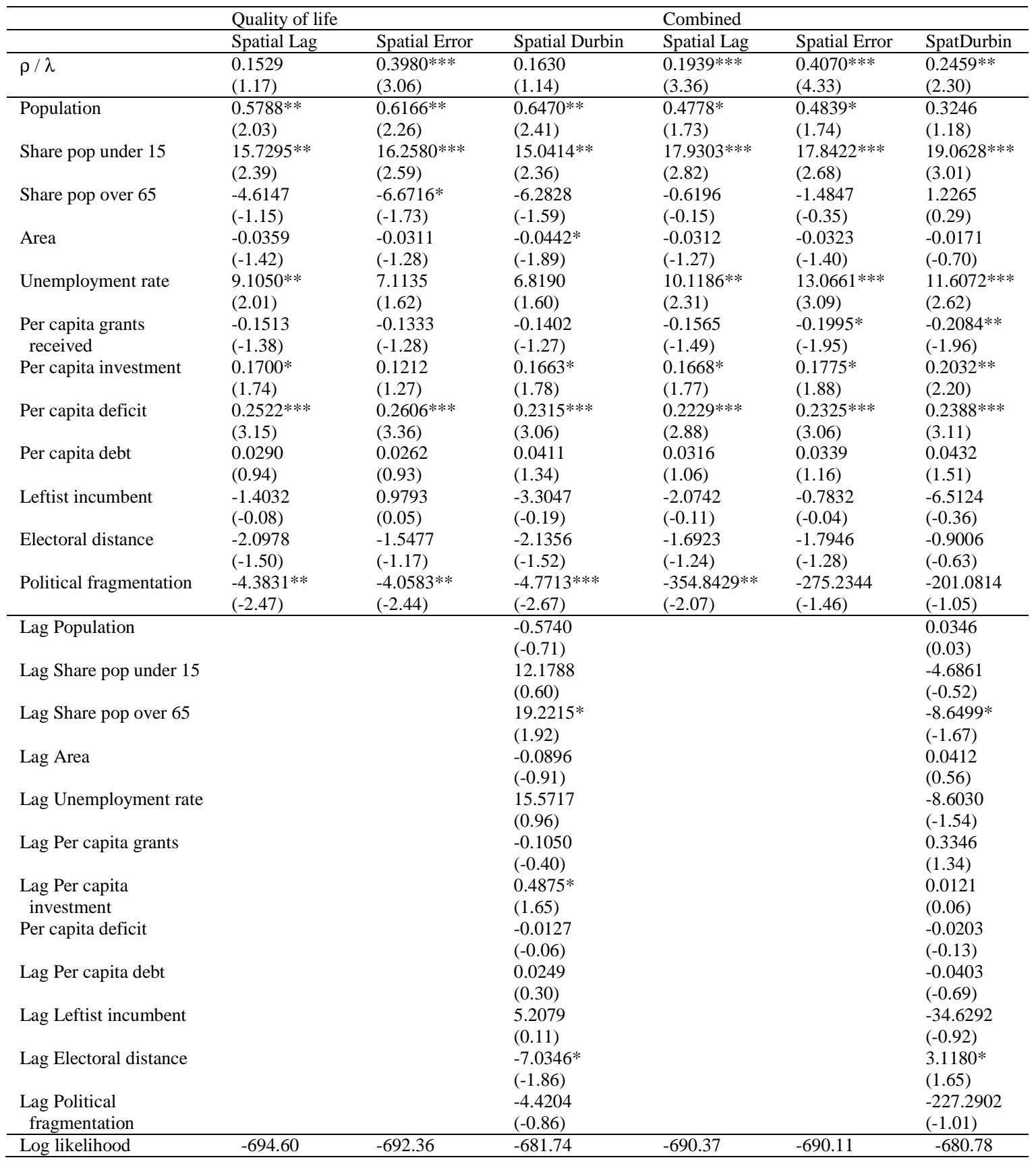

Source: own elaboration

$* * *, * *$ and $*$, significant at $1 \%, 5 \%$ and $10 \%$ respectively 
6b. Property tax: per capita liability

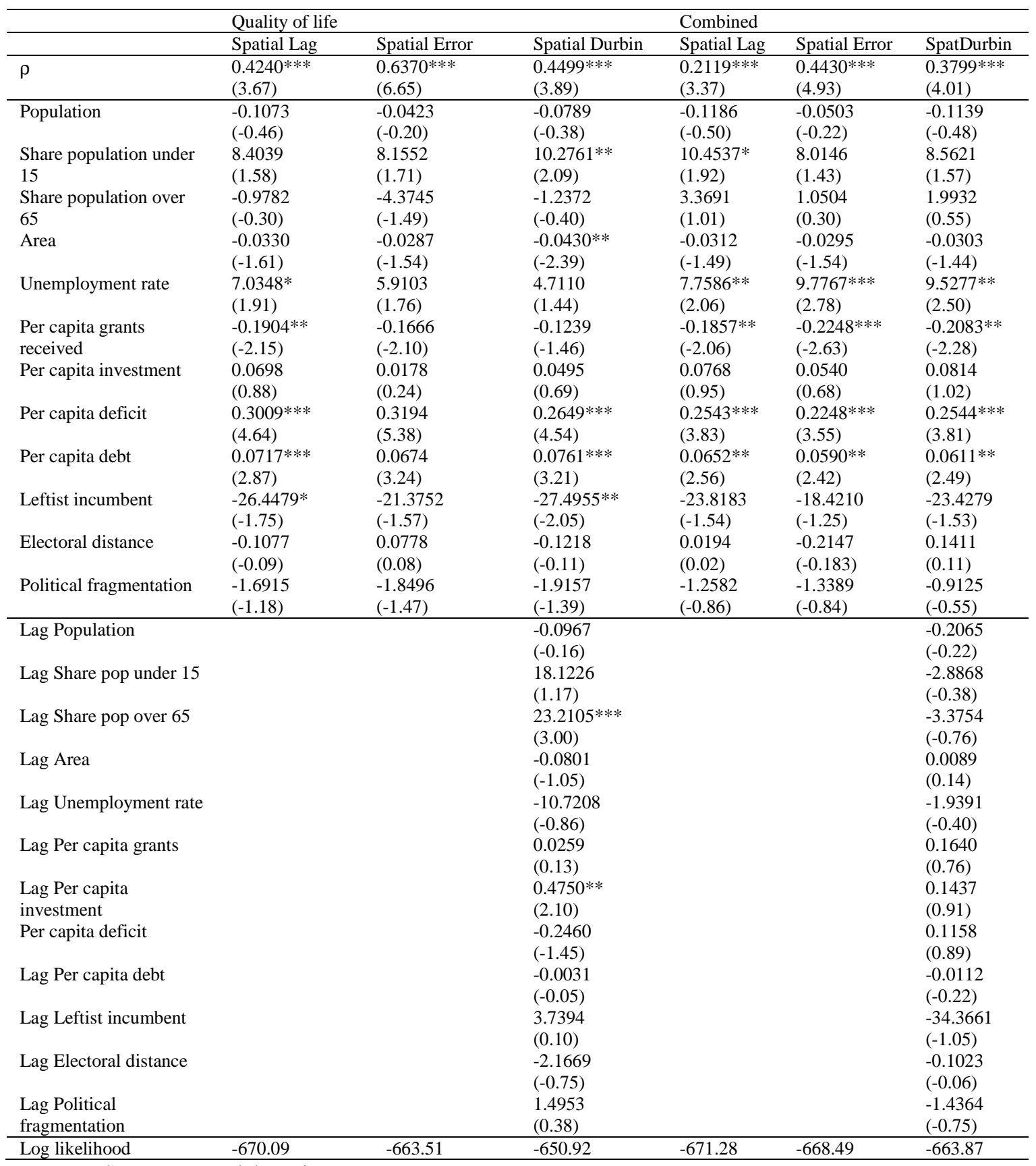

Source: own elaboration

$* * *, * *$ and $*$, significant at $1 \%, 5 \%$ and $10 \%$ respectively 
6c. Motor vehicle tax

\begin{tabular}{|c|c|c|c|c|c|c|}
\hline & Quality of life & & & Combined & & \\
\hline & Spatial Lag & Spatial Error & Spatial Durbin & Spatial Lag & Spatial Error & Spat Durbin \\
\hline \multirow[t]{2}{*}{$\rho$} & -0.0290 & 0.1540 & 0.0480 & 0.0239 & 0.1280 & 0.0139 \\
\hline & $(-0.19)$ & $(1.02)$ & $(0.32)$ & $(0.88)$ & $(1.07)$ & $(0.12)$ \\
\hline Population & $(1.00)$ & $(1.18)$ & $(1.10)$ & $(0.95)$ & $(1.02)$ & $(0.67)$ \\
\hline Share population under & -0.0024 & -0.0041 & -0.0031 & -0.0010 & -0.0022 & -0.0100 \\
\hline 15 & $(-0.17)$ & $(-0.29)$ & $(-0.22)$ & $(-0.07)$ & $(-0.15)$ & $(-0.75)$ \\
\hline \multirow[t]{2}{*}{ Area } & 0.0001 & 0.0001 & 0.0001 & 0.0001 & 0.0001 & 0.0001 \\
\hline & $(0.23)$ & $(0.03)$ & $(0.29)$ & $(0.30)$ & $(0.30)$ & $(1.26)$ \\
\hline \multirow[t]{2}{*}{ Unemployment rate } & -0.0045 & -0.0038 & 0.0001 & -0.0050 & -0.0033 & -0.0089 \\
\hline & $(-0.45)$ & $(-0.38)$ & $(0.00)$ & $(-0.50)$ & $(-0.33)$ & $(-0.95)$ \\
\hline $\begin{array}{l}\text { Per capita grants } \\
\text { received }\end{array}$ & $0.0006^{* *}$ & $0.0006^{* * *}$ & $0.0005^{*}$ & $0.0006^{* *}$ & $0.0006^{* *}$ & 0.0003 \\
\hline Per capita deficit & $(-1.87)$ & $(-2.02)$ & $(-1.40)$ & $(-1.96)$ & $(-1.54)$ & $(-0.76)$ \\
\hline \multirow[t]{2}{*}{ Per capita debt } & -0.0001 & -0.0001 & -0.0001 & -0.0001 & -0.0001 & -0.0001 \\
\hline & $(-0.48)$ & $(-0.40)$ & $(-0.88)$ & $(-0.43)$ & $(-0.53)$ & $(-0.59)$ \\
\hline \multirow[t]{2}{*}{ Leftist incumbent } & 0.0508 & 0.0526 & 0.0473 & 0.0496 & 0.0460 & 0.0391 \\
\hline & $(1.25)$ & $(1.30)$ & $(1.22)$ & $(1.22)$ & $(1.13)$ & (1.04) \\
\hline \multirow[t]{2}{*}{ Electoral distance } & $-0.0053 *$ & $-0.0058 *$ & -0.0041 & -0.0049 & -0.0042 & 0.0012 \\
\hline & $(-1.75)$ & $(-1.92)$ & $(-1.33)$ & $(-1.61)$ & $(-1.36)$ & $(0.41)$ \\
\hline \multirow[t]{2}{*}{ Political fragmentation } & $-0.0094 * *$ & $-0.0101 * * *$ & $-0.0083^{* *}$ & $-0.0089 * *$ & $-0.0070^{* *}$ & 0.0014 \\
\hline & $(-2.45)$ & $(-2.66)$ & $(-2.09)$ & $(-2.29)$ & $(-1.76)$ & $(0.34)$ \\
\hline \multirow[t]{2}{*}{ Lag Population } & & & -0.0025 & & & -0.0015 \\
\hline & & & $(-1.42)$ & & & $(-0.65)$ \\
\hline \multirow[t]{2}{*}{ Lag Per capita grants } & & & -0.0006 & & & 0.0003 \\
\hline & & & $(-1.06)$ & & & $(0.50)$ \\
\hline Lag Per capita & & & 0.0001 & & & 0.0001 \\
\hline investment & & & $(0.10)$ & & & $(0.40)$ \\
\hline Lag Per capita deficit & & & 0.0006 & & & $-0.0008 * * *$ \\
\hline & & & $(1.16)$ & & & $(-2.63)$ \\
\hline Lag Per capita debt & & & -0.0001 & & & -0.0001 \\
\hline & & & $(-0.66)$ & & & $(-0.83)$ \\
\hline Lag Leftist incumbent & & & -0.1255 & & & 0.0013 \\
\hline & & & $(-1.19)$ & & & $(0.01)$ \\
\hline Lag Electoral distance & & & 0.0073 & & & -0.0028 \\
\hline & & & $(0.88)$ & & & $(-0.72)$ \\
\hline Lag Political & & & 0.0106 & & & $-0.0167 * * *$ \\
\hline fragmentation & & & $(0.92)$ & & & $(-3.61)$ \\
\hline Log likelihood & 71.92 & 72.29 & 82.04 & 72.28 & 72.11 & 90.61 \\
\hline
\end{tabular}

Source: own elaboration

$* * *, * *$ and $*$, significant at $1 \%, 5 \%$ and $10 \%$ respectively 
Table 7. Direct and indirect effects - K=4-nearest neighbors and distance-50 km

7.a. Property tax - per receipt liability

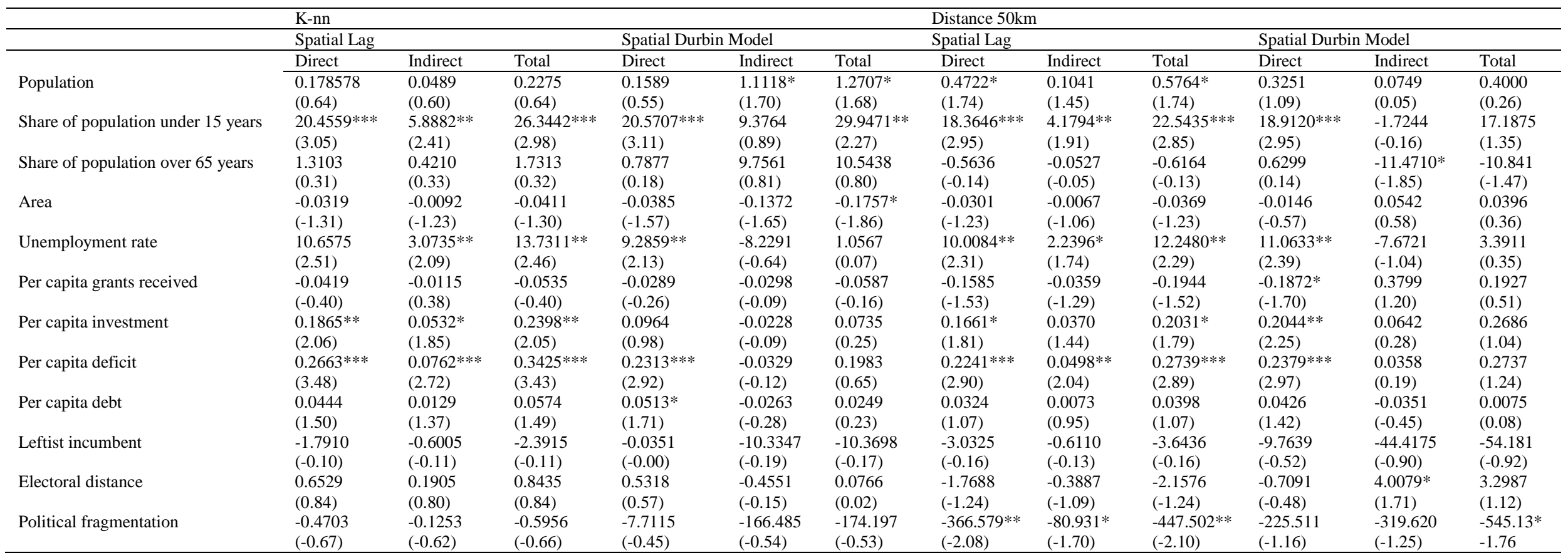

$* * *, * *$ and $*$ indicate significance at the $1 \%, 5 \%$ and $10 \%$ levels, respectively. 
7.b. Property tax - per capita liability

\begin{tabular}{|c|c|c|c|c|c|c|c|c|c|c|c|c|}
\hline & \multicolumn{6}{|l|}{ K-nn } & \multicolumn{6}{|c|}{ Distance $50 \mathrm{~km}$} \\
\hline & Spatial Lag & & & Spatial Dur & Model & & Spatial Lag & & & Spatial Du & in Model & \\
\hline \multirow{3}{*}{ Population } & Direct & Indirect & Total & Direct & Indirect & Total & Direct & Indirect & Total & Direct & Indirect & Total \\
\hline & -0.2924 & -0.0758 & -0.3683 & -0.5956 & 0.1196 & -0.2341 & -0.1160 & -0.0293 & -0.1453 & -0.1436 & -0.5119 & -0.6556 \\
\hline & $(-1.21)$ & $(-1.06)$ & $(-1.19)$ & $(-0.66)$ & $(0.21)$ & $(-0.36)$ & $(-0.49)$ & $(-0.45)$ & $(-0.49)$ & $(-0.51)$ & $(-0.35)$ & $(-0.41)$ \\
\hline Share of population under 15 years & $\begin{array}{l}11.9847 * * \\
(2.08)\end{array}$ & $\begin{array}{l}2.9815^{*} \\
(1.69)\end{array}$ & $\begin{array}{l}14.9663 * * \\
(2.05)\end{array}$ & $\begin{array}{l}10.8904 * \\
(1.90)\end{array}$ & $\begin{array}{l}-1.3792 \\
(-0.15)\end{array}$ & $\begin{array}{l}9.5111 \\
(0.83)\end{array}$ & $\begin{array}{l}10.5680 * \\
(1.86)\end{array}$ & $\begin{array}{l}2.7482 \\
(1.44)\end{array}$ & $\begin{array}{l}13.3163 * \\
(1.82)\end{array}$ & $\begin{array}{l}8.7363 \\
(1.58)\end{array}$ & $\begin{array}{l}-1.0449 \\
(-0.09)\end{array}$ & $\begin{array}{l}7.6914 \\
(0.55)\end{array}$ \\
\hline Share of population over 65 years & $\begin{array}{l}4.3817 \\
(1.23)\end{array}$ & $\begin{array}{l}1.1225 \\
(1.08)\end{array}$ & $\begin{array}{l}5.5043 \\
(1.22)\end{array}$ & $\begin{array}{l}3.0463 \\
(0.82)\end{array}$ & $\begin{array}{l}7.1713 \\
(0.71)\end{array}$ & $\begin{array}{l}10.2177 \\
(0.92)\end{array}$ & $\begin{array}{l}3.4323 \\
(1.00)\end{array}$ & $\begin{array}{l}0.9323 \\
(0.89)\end{array}$ & $\begin{array}{l}4.3646 \\
(0.99)\end{array}$ & $\begin{array}{l}1.8033 \\
(0.48)\end{array}$ & $\begin{array}{l}-4.8410 \\
(-0.73)\end{array}$ & $\begin{array}{l}-3.0376 \\
(-0.36)\end{array}$ \\
\hline Area & $\begin{array}{l}-0.0310 \\
(-1.50)\end{array}$ & $\begin{array}{l}-0.0077 \\
(-1.31)\end{array}$ & $\begin{array}{l}-0.0388 \\
(-1.48)\end{array}$ & $\begin{array}{l}-0.0335 \\
(-1.60)\end{array}$ & $\begin{array}{l}-0.10124 \\
(-1.44)\end{array}$ & $\begin{array}{l}-0.1347 * \\
(-1.70)\end{array}$ & $\begin{array}{l}-0.0310 \\
(-1.49)\end{array}$ & $\begin{array}{l}-0.0078 \\
(-1.26)\end{array}$ & $\begin{array}{l}-0.0389 \\
(-1.48)\end{array}$ & $\begin{array}{l}-0.0309 \\
(-1.23)\end{array}$ & $\begin{array}{l}0.0030 \\
(0.03)\end{array}$ & $\begin{array}{l}-0.0278 \\
(-0.23)\end{array}$ \\
\hline Unemployment rate & $\begin{array}{l}8.1941 * * \\
(2.24)\end{array}$ & $\begin{array}{l}2.0613^{*} \\
(1.73)\end{array}$ & $\begin{array}{l}10.2554 * * \\
(2.19)\end{array}$ & $\begin{array}{l}6.0312 \\
(1.61)\end{array}$ & $\begin{array}{l}-9.8988 \\
(-0.85)\end{array}$ & $\begin{array}{l}-3.8676 \\
(-0.29)\end{array}$ & $\begin{array}{l}7.9780 * * \\
(2.14)\end{array}$ & $\begin{array}{l}2.0087 * \\
(1.67)\end{array}$ & $\begin{array}{l}9.9868 * * \\
(2.12)\end{array}$ & $\begin{array}{l}9.4354 * * \\
(2.41)\end{array}$ & $\begin{array}{l}1.7001 \\
(0.22)\end{array}$ & $\begin{array}{l}11.1354 \\
(1.16)\end{array}$ \\
\hline Per capita grants received & $\begin{array}{l}-0.1108 \\
(-1.22)\end{array}$ & $\begin{array}{l}-0.0271 \\
(-1.09)\end{array}$ & $\begin{array}{l}-0.1379 \\
(-1.21)\end{array}$ & $\begin{array}{l}-0.0884 \\
(-0.95)\end{array}$ & $\begin{array}{l}-0.1537 \\
(-0.63)\end{array}$ & $\begin{array}{l}-0.2422 \\
(-0.88)\end{array}$ & $\begin{array}{l}-0.1913^{* *} \\
(-2.09)\end{array}$ & $\begin{array}{l}-0.0487 \\
(-1.60)\end{array}$ & $\begin{array}{l}-0.2401 * * \\
(-2.06)\end{array}$ & $\begin{array}{l}-0.1980 * \\
(-1.94)\end{array}$ & $\begin{array}{l}0.1607 \\
(0.48)\end{array}$ & $\begin{array}{l}-0.0373 \\
(-0.09)\end{array}$ \\
\hline Per capita investment & $\begin{array}{l}0.0825 \\
(1.05)\end{array}$ & $\begin{array}{l}0.0202 \\
(0.97)\end{array}$ & $\begin{array}{l}0.1028 \\
(1.04)\end{array}$ & $\begin{array}{l}0.0629 \\
(0.75)\end{array}$ & $\begin{array}{l}0.2144 \\
(0.99)\end{array}$ & $\begin{array}{l}0.2773 \\
(1.10)\end{array}$ & $\begin{array}{l}0.0801 \\
(0.96)\end{array}$ & $\begin{array}{l}0.0203 \\
(0.87)\end{array}$ & $\begin{array}{l}0.1005 \\
(0.96)\end{array}$ & $\begin{array}{l}0.1019 \\
(1.24)\end{array}$ & $\begin{array}{l}0.2378 \\
(0.99)\end{array}$ & $\begin{array}{l}0.3398 \\
(1.23)\end{array}$ \\
\hline Per capita deficit & $\begin{array}{l}0.2870 * * * \\
(4.36)\end{array}$ & $\begin{array}{l}0.0710 * * * \\
(2.69)\end{array}$ & $\begin{array}{l}0.35810 * * * \\
(4.24)\end{array}$ & $\begin{array}{l}0.2805 * * * \\
(4.21)\end{array}$ & $\begin{array}{l}0.3696 \\
(1.60)\end{array}$ & $\begin{array}{l}0.6502^{* * *} \\
(2.53)\end{array}$ & $\begin{array}{l}0.2596 \text { **** } \\
(3.91)\end{array}$ & $\begin{array}{l}0.0657 * * \\
(2.32)\end{array}$ & $\begin{array}{l}0.3253 \text { *** } \\
(3.83)\end{array}$ & $\begin{array}{l}0.2779 \text { *** } \\
(3.84)\end{array}$ & $\begin{array}{l}0.2970 \\
(1.53)\end{array}$ & $\begin{array}{l}0.5750 \text { *** } \\
(2.47)\end{array}$ \\
\hline Per capita debt & $\begin{array}{l}0.0714 * * * * \\
(2.79)\end{array}$ & $\begin{array}{l}0.0179^{* *} \\
(2.03)\end{array}$ & $\begin{array}{l}0.0893 * * * \\
(2.72)\end{array}$ & $\begin{array}{l}0.0581^{* *} \\
(2.15)\end{array}$ & $\begin{array}{l}-0.0471 \\
(-0.56)\end{array}$ & $\begin{array}{l}0.0109 \\
(0.11)\end{array}$ & $\begin{array}{l}0.0659 * * \\
(2.58)\end{array}$ & $\begin{array}{l}0.0168 * \\
(1.84)\end{array}$ & $\begin{array}{l}0.0827 * * \\
(2.53)\end{array}$ & $\begin{array}{l}0.0625 * * \\
(2.40)\end{array}$ & $\begin{array}{l}0.0224 \\
(0.28)\end{array}$ & $\begin{array}{l}0.0850 \\
(0.93)\end{array}$ \\
\hline Leftist incumbent & $\begin{array}{l}-28.7626^{*} \\
(-1.81)\end{array}$ & $\begin{array}{l}-7.1584 \\
(-1.51)\end{array}$ & $\begin{array}{l}-35.9211 * \\
(-1.78)\end{array}$ & $\begin{array}{l}-25.1934 \\
(-1.63)\end{array}$ & $\begin{array}{l}-40.4043 \\
(-0.92)\end{array}$ & $\begin{array}{l}-65.5977 \\
(-1.33)\end{array}$ & $\begin{array}{l}-24.0972 \\
(-1.58)\end{array}$ & $\begin{array}{l}-6.1492 \\
(-1.30)\end{array}$ & $\begin{array}{l}-30.2465 \\
(-1.56)\end{array}$ & $\begin{array}{l}-28.7248^{*} \\
(-1.72)\end{array}$ & $\begin{array}{l}-63.378 \\
(-1.21)\end{array}$ & $\begin{array}{l}-92.1033 \\
(-1.49)\end{array}$ \\
\hline Electoral distance & $\begin{array}{l}0.8451 \\
(1.17)\end{array}$ & $\begin{array}{l}0.2097 \\
(1.07)\end{array}$ & $\begin{array}{l}1.0549 \\
(1.17)\end{array}$ & $\begin{array}{l}0.6169 \\
(0.77)\end{array}$ & $\begin{array}{l}0.5920 \\
(0.23)\end{array}$ & $\begin{array}{l}1.2089 \\
(0.40)\end{array}$ & $\begin{array}{l}-0.0321 \\
(-0.02)\end{array}$ & $\begin{array}{l}-0.0006 \\
(-0.00)\end{array}$ & $\begin{array}{l}-0.0327 \\
(-0.02)\end{array}$ & $\begin{array}{l}0.1280 \\
(0.10)\end{array}$ & $\begin{array}{l}0.2913 \\
(0.11)\end{array}$ & $\begin{array}{l}0.4192 \\
(0.13)\end{array}$ \\
\hline Political fragmentation & $\begin{array}{l}-0.1314 \\
(-0.21)\end{array}$ & $\begin{array}{l}-0.0246 \\
(-0.16)\end{array}$ & $\begin{array}{l}-0.1561 \\
(-0.20)\end{array}$ & $\begin{array}{l}7.1371 \\
(0.49)\end{array}$ & $\begin{array}{l}152.484 \\
(0.58)\end{array}$ & $\begin{array}{l}159.621 \\
(0.58)\end{array}$ & $\begin{array}{l}-130.705 \\
(-0.89)\end{array}$ & $\begin{array}{l}-32.452 \\
(-0.79)\end{array}$ & $\begin{array}{l}-163.158 \\
(-0.89)\end{array}$ & $\begin{array}{l}-110.505 \\
(-0.65)\end{array}$ & $\begin{array}{l}-238.006 \\
(-0.90)\end{array}$ & $\begin{array}{l}-348.511 \\
(-1.09)\end{array}$ \\
\hline
\end{tabular}

$* * *, * *$ and $*$ indicate significance at the $1 \%, 5 \%$ and $10 \%$ levels, respectively. 
Table 8. Direct and indirect effects - Quality of life and combined (distance-50 km \& quality of life)

8.a. Property tax - per receipt liability

\begin{tabular}{|c|c|c|c|c|c|c|c|c|c|c|c|c|}
\hline & \multicolumn{6}{|c|}{ Quality of life } & \multicolumn{6}{|l|}{ Combined } \\
\hline & Spatial Lag & & & Spatial Dur & in Model & & Spatial Lag & & & Spatial Dur & in Model & \\
\hline & Direct & Indirect & Total & Direct & Indirect & Total & Direct & Indirect & Total & Direct & Indirect & Total \\
\hline Population & $\begin{array}{l}0.5970 * * \\
(2.05)\end{array}$ & $\begin{array}{l}0.1214 \\
(0.86)\end{array}$ & $\begin{array}{l}0.7184 * \\
(1.90)\end{array}$ & $\begin{array}{l}0.6396^{* *} \\
(2.37)\end{array}$ & $\begin{array}{l}-0.5887 \\
(-0.60)\end{array}$ & $\begin{array}{l}0.0509 \\
(0.04)\end{array}$ & $\begin{array}{l}0.4623^{*} \\
(1.67)\end{array}$ & $\begin{array}{l}0.1080 \\
(1.40)\end{array}$ & $\begin{array}{l}0.5703^{*} \\
(1.67)\end{array}$ & $\begin{array}{l}0.3270 \\
(1.09)\end{array}$ & $\begin{array}{l}0.1429 \\
(0.10)\end{array}$ & $\begin{array}{l}0.4700 \\
(0.30)\end{array}$ \\
\hline $\begin{array}{l}\text { Share of population under } 15 \\
\text { years }\end{array}$ & $\begin{array}{l}15.9402^{* *} \\
(2.45)\end{array}$ & $\begin{array}{l}3.1489 \\
(0.88)\end{array}$ & $\begin{array}{l}19.0891 * * \\
(2.24)\end{array}$ & $\begin{array}{l}15.7152^{* *} \\
(2.39)\end{array}$ & $\begin{array}{l}16.5908 \\
(0.65)\end{array}$ & $\begin{array}{l}32.3060 \\
(1.16)\end{array}$ & $\begin{array}{l}17.8958 * * * \\
(2.68)\end{array}$ & $\begin{array}{l}4.2750^{*} \\
(1.80)\end{array}$ & $\begin{array}{l}22.1709^{* *} \\
(2.58)\end{array}$ & $\begin{array}{l}18.8679 * * * \\
(2.91)\end{array}$ & $\begin{array}{l}0.2809 \\
(0.02)\end{array}$ & $\begin{array}{l}19.1488 \\
(1.35)\end{array}$ \\
\hline Share of population over 65 years & $\begin{array}{l}-4.6622 \\
(-1.15)\end{array}$ & $\begin{array}{l}-0.8622 \\
(-0.65)\end{array}$ & $\begin{array}{l}-5.5245 \\
(-1.12)\end{array}$ & $\begin{array}{l}-5.7837 \\
(-1.45)\end{array}$ & $\begin{array}{l}21.3369^{*} \\
(1.68)\end{array}$ & $\begin{array}{l}15.5533 \\
(1.10)\end{array}$ & $\begin{array}{l}-0.7812 \\
(-0.18)\end{array}$ & $\begin{array}{l}-0.0868 \\
(-0.08)\end{array}$ & $\begin{array}{l}-0.8681 \\
(-0.16)\end{array}$ & $\begin{array}{l}0.4521 \\
(0.11)\end{array}$ & $\begin{array}{l}-10.6893 \\
(-1.63)\end{array}$ & $\begin{array}{l}-10.2371 \\
(-1.31)\end{array}$ \\
\hline Area & $\begin{array}{l}-0.0370 \\
(-1.46)\end{array}$ & $\begin{array}{l}-0.0073 \\
(-0.78)\end{array}$ & $\begin{array}{l}-0.0443 \\
(-1.41)\end{array}$ & $\begin{array}{l}-0.0464 * \\
(-1.92)\end{array}$ & $\begin{array}{l}-0.1182 \\
(-0.96)\end{array}$ & $\begin{array}{l}-0.1647 \\
(-1.24)\end{array}$ & $\begin{array}{l}-0.0321 \\
(-1.27)\end{array}$ & $\begin{array}{l}-0.0074 \\
(-1.11)\end{array}$ & $\begin{array}{l}-0.0395 \\
(-1.26)\end{array}$ & $\begin{array}{l}-0.0152 \\
(-0.57)\end{array}$ & $\begin{array}{l}0.0481 \\
(0.49)\end{array}$ & $\begin{array}{l}0.0328 \\
(0.29)\end{array}$ \\
\hline Unemployment rate & $\begin{array}{l}9.1905 * * \\
(2.02)\end{array}$ & $\begin{array}{l}1.8231 \\
(0.85)\end{array}$ & $\begin{array}{l}11.0137 * \\
(1.88)\end{array}$ & $\begin{array}{l}6.8952 \\
(1.60)\end{array}$ & $\begin{array}{l}19.4702 \\
(0.97)\end{array}$ & $\begin{array}{l}26.3653 \\
(1.26)\end{array}$ & $\begin{array}{l}10.5163^{* *} \\
(2.36)\end{array}$ & $\begin{array}{l}2.4553^{*} \\
(1.79)\end{array}$ & $\begin{array}{l}12.9716 * * \\
(2.34)\end{array}$ & $\begin{array}{l}11.5028 * * \\
(2.60)\end{array}$ & $\begin{array}{l}-6.8367 \\
(-0.94)\end{array}$ & $\begin{array}{l}4.6660 \\
(0.49)\end{array}$ \\
\hline Per capita grants received & $\begin{array}{l}-0.1527 \\
(-1.37)\end{array}$ & $\begin{array}{l}-0.0326 \\
(-0.74)\end{array}$ & $\begin{array}{l}-0.1853 \\
(-1.30)\end{array}$ & $\begin{array}{l}-0.1422 \\
(-1.26)\end{array}$ & $\begin{array}{l}-0.1401 \\
(-0.43)\end{array}$ & $\begin{array}{l}-0.2823 \\
(-0.76)\end{array}$ & $\begin{array}{l}-0.1607 \\
(-1.49)\end{array}$ & $\begin{array}{l}-0.0383 \\
(-1.27)\end{array}$ & $\begin{array}{l}-0.1991 \\
(-1.48)\end{array}$ & $\begin{array}{l}-0.1995^{*} \\
(-1.79)\end{array}$ & $\begin{array}{l}0.3301 \\
(0.97)\end{array}$ & $\begin{array}{l}0.1306 \\
(0.33)\end{array}$ \\
\hline Per capita investment & $\begin{array}{l}0.1763^{*} \\
(1.75)\end{array}$ & $\begin{array}{l}0.0361 \\
(0.83)\end{array}$ & $\begin{array}{l}0.2124 * * \\
(1.66)\end{array}$ & $\begin{array}{l}0.1801 * \\
(1.88)\end{array}$ & $\begin{array}{l}0.6100^{*} \\
(1.68)\end{array}$ & $\begin{array}{l}0.7901 \text { ** } \\
(2.06)\end{array}$ & $\begin{array}{l}0.1703^{*} \\
(1.73)\end{array}$ & $\begin{array}{l}0.0402 \\
(1.42)\end{array}$ & $\begin{array}{l}0.2106^{*} \\
(1.71)\end{array}$ & $\begin{array}{l}0.2117 * * \\
(2.24)\end{array}$ & $\begin{array}{l}0.0887 \\
(0.38)\end{array}$ & $\begin{array}{l}0.3005 \\
(1.18)\end{array}$ \\
\hline Per capita deficit & $\begin{array}{l}0.2561 * * * \\
(3.18)\end{array}$ & $\begin{array}{l}0.0517 \\
(0.96)\end{array}$ & $\begin{array}{l}0.3078 \text { *** } \\
(2.75)\end{array}$ & $\begin{array}{l}0.2305 * * * \\
(3.01)\end{array}$ & $\begin{array}{l}0.0215 \\
(0.08)\end{array}$ & $\begin{array}{l}0.2520 \\
(0.93)\end{array}$ & $\begin{array}{l}0.2256^{* * * *} \\
(2.96)\end{array}$ & $\begin{array}{l}0.0526 * * \\
(2.01)\end{array}$ & $\begin{array}{l}0.2782 * * * \\
(2.90)\end{array}$ & $\begin{array}{l}0.2478^{* * * *} \\
(3.20)\end{array}$ & $\begin{array}{l}0.0712 \\
(0.38)\end{array}$ & $\begin{array}{l}0.3190 \\
(1.46)\end{array}$ \\
\hline Per capita debt & $\begin{array}{l}0.0286 \\
(0.96)\end{array}$ & $\begin{array}{l}0.0057 \\
(0.60)\end{array}$ & $\begin{array}{l}0.0343 \\
(0.94)\end{array}$ & $\begin{array}{l}0.0413 \\
(1.33)\end{array}$ & $\begin{array}{l}0.0388 \\
(0.36)\end{array}$ & $\begin{array}{l}0.0800 \\
(0.65)\end{array}$ & $\begin{array}{l}0.0340 \\
(1.14)\end{array}$ & $\begin{array}{l}0.0080 \\
(1.01)\end{array}$ & $\begin{array}{l}0.04211 \\
(1.14)\end{array}$ & $\begin{array}{l}0.042076 \\
(1.45)\end{array}$ & $\begin{array}{l}-0.0339 \\
(-0.44)\end{array}$ & $\begin{array}{l}0.0081 \\
(0.09)\end{array}$ \\
\hline Leftist incumbent & $\begin{array}{l}-0.7306 \\
(-0.03)\end{array}$ & $\begin{array}{l}-0.1669 \\
(-0.03)\end{array}$ & $\begin{array}{l}-0.8975 \\
(-0.04)\end{array}$ & $\begin{array}{l}-3.0049 \\
(-0.16)\end{array}$ & $\begin{array}{l}6.0725^{*} \\
(0.09)\end{array}$ & $\begin{array}{l}3.0677 \\
(0.04)\end{array}$ & $\begin{array}{l}-1.9871 \\
(-0.11)\end{array}$ & $\begin{array}{l}-0.5058 \\
(-0.11)\end{array}$ & $\begin{array}{l}-2.4930 \\
(-0.11)\end{array}$ & $\begin{array}{l}-8.1182 \\
(-0.44)\end{array}$ & $\begin{array}{l}-42.9539 \\
(-0.85)\end{array}$ & $\begin{array}{l}-51.0722 \\
(-0.85)\end{array}$ \\
\hline Electoral distance & $\begin{array}{l}-2.0814 \\
(-1.48)\end{array}$ & $\begin{array}{l}-0.4062 \\
(-0.75)\end{array}$ & $\begin{array}{l}-2.4876 \\
(-1.42)\end{array}$ & $\begin{array}{l}-2.2714 \\
(-1.56)\end{array}$ & $\begin{array}{l}-8.7858 * \\
(-1.88)\end{array}$ & $\begin{array}{l}-11.0573 \\
(-2.10)\end{array}$ & $\begin{array}{l}-1.7777 \\
(-1.30)\end{array}$ & $\begin{array}{l}-0.4058 \\
(-1.18)\end{array}$ & $\begin{array}{l}-2.1835 \\
(-1.30)\end{array}$ & $\begin{array}{l}-0.7140 \\
(-0.48)\end{array}$ & $\begin{array}{l}3.6708 \\
(1.49)\end{array}$ & $\begin{array}{l}2.9567 \\
(0.96)\end{array}$ \\
\hline Political fragmentation & $\begin{array}{l}-4.3615^{* *} \\
(-2.48)\end{array}$ & $\begin{array}{l}-0.8455 \\
(-0.92) \\
\end{array}$ & $\begin{array}{l}-5.2071 * * \\
(-2.30)\end{array}$ & $\begin{array}{l}-4.8736 * * * \\
(-2.62)\end{array}$ & $\begin{array}{l}-6.1627 \\
(-0.97) \\
\end{array}$ & $\begin{array}{l}-11.036^{* *} \\
(-1.53)\end{array}$ & $\begin{array}{l}-368.424 * * \\
(-2.07)\end{array}$ & $\begin{array}{l}-85.110^{*} \\
(-1.70)\end{array}$ & $\begin{array}{l}-453.535^{* *} \\
-2.07\end{array}$ & $\begin{array}{l}-218.099 \\
(-1.16)\end{array}$ & $\begin{array}{l}-358.060 \\
(-1.34) \\
\end{array}$ & $\begin{array}{l}-576.160^{*} \\
(-1.83)\end{array}$ \\
\hline
\end{tabular}


8.b. Property tax - per capita liability

\begin{tabular}{|c|c|c|c|c|c|c|c|c|c|c|c|c|}
\hline & \multicolumn{6}{|c|}{ Quality of life } & \multicolumn{6}{|l|}{ Combined } \\
\hline & Spatial Lag & & & Spatial Du & Model & & Spatial Lą & & & Spatial Dur & Model & \\
\hline & Direct & Indirect & Total & Direct & Indirect & Total & Direct & Indirect & Total & Direct & Indirect & Total \\
\hline \multirow[t]{2}{*}{ Population } & -0.1129 & -0.0862 & $\begin{array}{l}-0.1991 \\
\end{array}$ & $\begin{array}{l}-0.0966 \\
\end{array}$ & -0.2820 & -0.3786 & -0.1209 & $\begin{array}{l}-0.0319 \\
\end{array}$ & -0.1529 & -0.1426 & -0.3937 & -0.5363 \\
\hline & $(-0.47)$ & $(-0.44)$ & $(-0.46)$ & $(-0.42)$ & $(-0.23)$ & $(0.28)$ & $(-0.50)$ & $(-0.46)$ & $(-0.50)$ & $(-0.51)$ & $(-0.27)$ & $(-0.33)$ \\
\hline Share of population under 15 years & $\begin{array}{l}8.7362 \\
(1.65)\end{array}$ & $\begin{array}{l}6.4786 \\
(1.15)\end{array}$ & $\begin{array}{l}15.2149 \\
(1.50)\end{array}$ & $\begin{array}{l}12.2805^{* *} \\
(2.23)\end{array}$ & $\begin{array}{l}39.4316 \\
(1.31)\end{array}$ & $\begin{array}{l}51.7121 \\
(1.56)\end{array}$ & $\begin{array}{l}10.3268^{*} \\
(1.82)\end{array}$ & $\begin{array}{l}2.7279 \\
(1.48)\end{array}$ & $\begin{array}{l}13.0548 * \\
(1.80)\end{array}$ & $\begin{array}{l}8.1940 \\
(1.42)\end{array}$ & $\begin{array}{l}0.3467 \\
(0.03)\end{array}$ & $\begin{array}{l}8.5407 \\
(0.61)\end{array}$ \\
\hline Share of population over 65 years & $\begin{array}{l}-0.9015 \\
(-0.28)\end{array}$ & $\begin{array}{l}-0.6073 \\
(-0.23)\end{array}$ & $\begin{array}{l}-1.5089 \\
(-0.26)\end{array}$ & $\begin{array}{l}0.8295 \\
(0.24)\end{array}$ & $\begin{array}{l}39.4400 \text { ** } \\
(2.50)\end{array}$ & $\begin{array}{l}40.2695^{* * *} \\
(2.31)\end{array}$ & $\begin{array}{l}3.2573 \\
(0.92)\end{array}$ & $\begin{array}{l}0.9036 \\
(0.85)\end{array}$ & $\begin{array}{l}4.1610 \\
(0.92)\end{array}$ & $\begin{array}{l}1.5016 \\
(0.41)\end{array}$ & $\begin{array}{l}-4.3153 \\
(-0.69)\end{array}$ & $\begin{array}{l}-2.8136 \\
(-0.36)\end{array}$ \\
\hline Area & $\begin{array}{l}-0.0337 \\
(-1.59)\end{array}$ & $\begin{array}{l}-0.0250 \\
(-1.16)\end{array}$ & $\begin{array}{l}-0.0587 \\
(-1.46)\end{array}$ & $\begin{array}{l}-0.0514 * * \\
(-2.40)\end{array}$ & $\begin{array}{l}-0.1772 \\
(-1.20)\end{array}$ & $\begin{array}{l}-0.2286 \\
(-1.44)\end{array}$ & $\begin{array}{l}-0.0303 \\
(-1.42)\end{array}$ & $\begin{array}{l}-0.0078 \\
(-1.22)\end{array}$ & $\begin{array}{l}-0.0382 \\
(-1.42)\end{array}$ & $\begin{array}{l}-0.0309 \\
(-1.22)\end{array}$ & $\begin{array}{l}-0.0042 \\
(-0.04)\end{array}$ & $\begin{array}{l}-0.0351 \\
(-0.29)\end{array}$ \\
\hline Unemployment rate & $\begin{array}{l}7.3423^{*} \\
(1.88)\end{array}$ & $\begin{array}{l}5.5138 \\
(1.26)\end{array}$ & $\begin{array}{l}12.8562 * \\
(1.67)\end{array}$ & $\begin{array}{l}3.9000 \\
(1.04)\end{array}$ & $\begin{array}{l}-15.3964 \\
(-0.66)\end{array}$ & $\begin{array}{l}-11.4964 \\
(-0.45)\end{array}$ & $\begin{array}{l}7.7623 * * \\
(2.04)\end{array}$ & $\begin{array}{l}1.9875^{*} \\
(1.66)\end{array}$ & $\begin{array}{l}9.7499 * * \\
(2.04)\end{array}$ & $\begin{array}{l}9.6918 * * \\
(2.40)\end{array}$ & $\begin{array}{l}2.5374 \\
(0.34)\end{array}$ & $\begin{array}{l}12.2293 \\
(1.29)\end{array}$ \\
\hline Per capita grants received & $\begin{array}{l}-0.1945^{\text {*** }} \\
(-2.08)\end{array}$ & $\begin{array}{l}-0.1453 \\
(-1.30)\end{array}$ & $\begin{array}{l}-0.3399 * \\
(-1.81)\end{array}$ & $\begin{array}{l}-0.1311 \\
(-1.36)\end{array}$ & $\begin{array}{l}-0.0479 \\
(-0.12)\end{array}$ & $\begin{array}{l}-0.1790 \\
(-0.39)\end{array}$ & $\begin{array}{l}-0.1904 * * \\
(-2.07)\end{array}$ & $\begin{array}{l}-0.0495 \\
(-1.63)\end{array}$ & $\begin{array}{l}-0.2399 * * \\
(-2.05)\end{array}$ & $\begin{array}{l}-0.2020 * * \\
(-2.03)\end{array}$ & $\begin{array}{l}0.1359 \\
(0.41)\end{array}$ & $\begin{array}{l}-0.0660 \\
(-0.17)\end{array}$ \\
\hline Per capita investment & $\begin{array}{l}0.0740 \\
(0.92)\end{array}$ & $\begin{array}{l}0.0563 \\
(0.77)\end{array}$ & $\begin{array}{l}0.1304 \\
(0.89)\end{array}$ & $\begin{array}{l}0.0927 \\
(1.25)\end{array}$ & $\begin{array}{l}0.8631^{*} \\
(2.11)\end{array}$ & $\begin{array}{l}0.9558 * * \\
(2.19)\end{array}$ & $\begin{array}{l}0.0761 \\
(0.97)\end{array}$ & $\begin{array}{l}0.0199 \\
(0.89)\end{array}$ & $\begin{array}{l}0.0960 \\
(0.97)\end{array}$ & $\begin{array}{l}0.1057 \\
(1.29)\end{array}$ & $\begin{array}{l}0.2654 \\
(1.12)\end{array}$ & $\begin{array}{l}0.3712 \\
(1.36)\end{array}$ \\
\hline Per capita deficit & $\begin{array}{l}0.3121^{* * * *} \\
(4.74)\end{array}$ & $\begin{array}{l}0.2313^{*} \\
(1.81)\end{array}$ & $\begin{array}{l}0.5433 \text { *** } \\
(3.25)\end{array}$ & $\begin{array}{l}0.2550 \text { **** } \\
(4.22)\end{array}$ & $\begin{array}{l}-0.2212 \\
(-0.75)\end{array}$ & $\begin{array}{l}0.0338 \\
(0.10)\end{array}$ & $\begin{array}{l}0.2604 * * * \\
(3.87)\end{array}$ & $\begin{array}{l}0.0675^{* *} \\
(2.36)\end{array}$ & $\begin{array}{l}0.3279 * * * * \\
(3.82)\end{array}$ & $\begin{array}{l}0.2838^{* * * *} \\
(4.00)\end{array}$ & $\begin{array}{l}0.3246 * \\
(1.71)\end{array}$ & $\begin{array}{l}0.6084 * * * \\
(2.71)\end{array}$ \\
\hline Per capita debt & $\begin{array}{l}0.0751^{* * * *} \\
(2.87)\end{array}$ & $\begin{array}{l}0.0556 \\
(1.64)\end{array}$ & $\begin{array}{l}0.1308^{* *} \\
(2.44)\end{array}$ & $\begin{array}{l}0.0809^{* * * *} \\
(2.92)\end{array}$ & $\begin{array}{l}0.0680 \\
(0.50)\end{array}$ & $\begin{array}{l}0.1489 \\
(0.95)\end{array}$ & $\begin{array}{l}0.0662 * * * * \\
(2.64)\end{array}$ & $\begin{array}{l}0.0173^{*} \\
(1.86)\end{array}$ & $\begin{array}{l}0.0835^{* *} \\
(2.58)\end{array}$ & $\begin{array}{l}0.0621^{* *} \\
(2.33)\end{array}$ & $\begin{array}{l}0.0202 \\
(0.24)\end{array}$ & $\begin{array}{l}0.0824 \\
(0.85)\end{array}$ \\
\hline Leftist incumbent & $\begin{array}{l}-26.7952^{*} \\
(-1.70)\end{array}$ & $\begin{array}{l}-20.0328 \\
(-1.15)\end{array}$ & $\begin{array}{l}-46.8281 \\
(-1.51)\end{array}$ & $\begin{array}{l}-27.7336^{*} \\
(-1.91)\end{array}$ & $\begin{array}{l}-15.4679 \\
(-0.22)\end{array}$ & $\begin{array}{l}-43.2015 \\
(-0.55)\end{array}$ & $\begin{array}{l}-24.6190 \\
(-1.55)\end{array}$ & $\begin{array}{l}-6.4448 \\
(-1.31)\end{array}$ & $\begin{array}{l}-31.0638 \\
(-1.54)\end{array}$ & $\begin{array}{l}-28.7019 * \\
(-1.75)\end{array}$ & $\begin{array}{l}-67.2764 \\
(-1.32)\end{array}$ & $\begin{array}{l}-95.9783 \\
(-1.59)\end{array}$ \\
\hline Electoral distance & $\begin{array}{l}-0.0750 \\
(-0.06)\end{array}$ & $\begin{array}{l}-0.0439 \\
(-0.04)\end{array}$ & $\begin{array}{l}-0.1189 \\
(-0.06)\end{array}$ & $\begin{array}{l}-0.3268 \\
(-0.27)\end{array}$ & $\begin{array}{l}-3.8930 \\
(-0.72)\end{array}$ & $\begin{array}{l}-4.2198 \\
(-0.69)\end{array}$ & $\begin{array}{l}0.0636 \\
(0.05)\end{array}$ & $\begin{array}{l}0.0250 \\
(0.07)\end{array}$ & $\begin{array}{l}0.0886 \\
(0.05)\end{array}$ & $\begin{array}{l}0.1748 \\
(0.14)\end{array}$ & $\begin{array}{l}-0.0785 \\
(-0.03)\end{array}$ & $\begin{array}{l}0.0963 \\
(0.03)\end{array}$ \\
\hline Political fragmentation & $\begin{array}{l}-1.6550 \\
(-1.13)\end{array}$ & $\begin{array}{l}-1.2011 \\
(-0.87)\end{array}$ & $\begin{array}{l}-2.8561 \\
(-1.06)\end{array}$ & $\begin{array}{l}-1.8617 \\
(-1.22)\end{array}$ & $\begin{array}{l}1.1204 \\
(0.15)\end{array}$ & $\begin{array}{l}-0.7412 \\
(-0.08) \\
\end{array}$ & $\begin{array}{l}-1.2879 \\
(-0.85) \\
\end{array}$ & $\begin{array}{l}-0.3304 \\
(-0.77)\end{array}$ & $\begin{array}{l}-1.6184 \\
(-0.84) \\
\end{array}$ & $\begin{array}{l}-1.0898 \\
(-0.69) \\
\end{array}$ & $\begin{array}{l}-2.6910 \\
(-1.03) \\
\end{array}$ & $\begin{array}{l}-3.7809 \\
(-1.21)\end{array}$ \\
\hline
\end{tabular}

$* * *, * *$ and $*$ indicate significance at the $1 \%, 5 \%$ and $10 \%$ levels, respectively. 
Table 9

Two-regime estimations: ideology

\begin{tabular}{cccc}
\hline & $\begin{array}{c}\text { Property tax - } \\
\text { Per receipt liability }\end{array}$ & $\begin{array}{c}\text { Property tax - } \\
\text { Per capita liability }\end{array}$ & $\begin{array}{c}\text { Motor vehicle } \\
\text { tax }\end{array}$ \\
\hline$\rho_{\text {total }}$ & 0.1529 & $0.4240^{* * *}$ & -0.0290 \\
overall sample & $(1.17)$ & $(3.67)$ & $(-0.19)$ \\
$\rho_{\text {left }}$ & -0.0001 & $0.368^{* * * *}$ & 0.010 \\
left-wing party & $(-0.001)$ & $(2.04)$ & $(0.0415)$ \\
$\rho_{\text {no-left }}$ & $0.355^{*}$ & $0.485^{* * *}$ & -0.075 \\
non-left party & $(1.842)$ & $(2.704)$ & $(-0.323)$ \\
& & & \\
difference & 0.3557 & 0.1170 & -0.0862 \\
(t-value) & $(1.19)$ & $(0.4226)$ & $(-0.2282)$ \\
\hline
\end{tabular}

Source: own elaboration

$* * *$ and $*$, significant at $1 \%$ and $10 \%$ respectively. Spatial lag model

Table 10

Two-regime estimations: majorities

\begin{tabular}{cccc}
\hline & $\begin{array}{c}\text { Property tax - } \\
\text { Per receipt liability }\end{array}$ & $\begin{array}{c}\text { Property tax - } \\
\text { Per capita liability }\end{array}$ & $\begin{array}{c}\text { Motor vehicle } \\
\text { tax }\end{array}$ \\
\hline$\rho_{\text {total }}$ & 0.1529 & $0.4240^{* * *}$ & -0.0290 \\
overall sample & $(1.17)$ & $(3.67)$ & $(-0.19)$ \\
$\rho_{\text {sm }}$ & 0.1622 & $0.5480 * * *$ & -0.1830 \\
strong majority & $(-0.966)$ & $(3.876)$ & $(-0.945)$ \\
$\rho_{\text {nsm }}$ & 0.1822 & $0.1960 * * *$ & 0.1840 \\
non strong & $(0.762)$ & $(0.890)$ & $(0.627)$ \\
majority & & & \\
difference & 0.0200 & -0.3530 & 0.3678 \\
$(t-v a l u e)$ & $(0.064)$ & $(-1.268)$ & $(0.970)$ \\
\hline
\end{tabular}

Source: own elaboration

$* * *$ significant at $1 \%$. Spatial lag model 